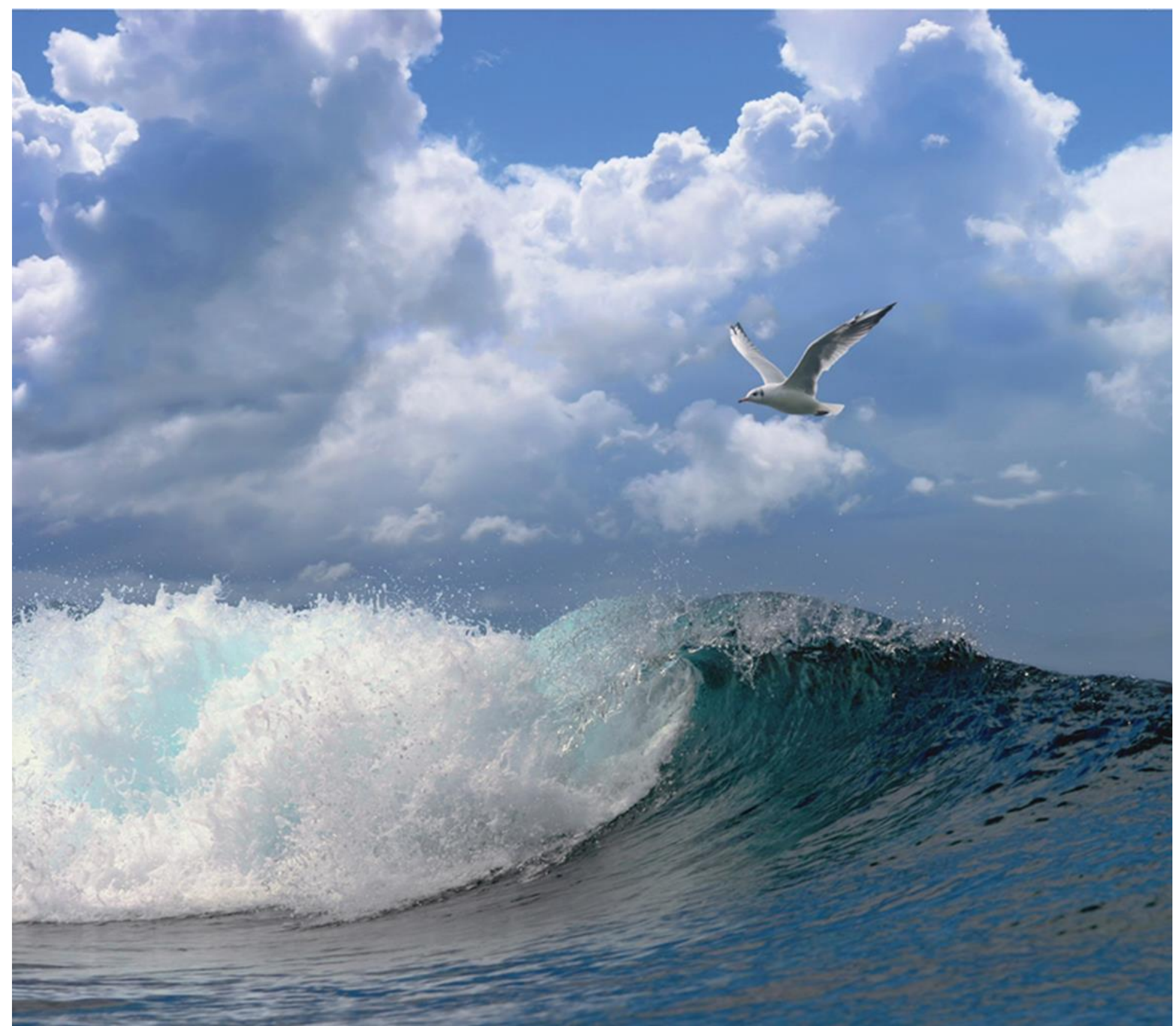

\title{
Ontwikkeling van prooidieren voor steltlopers van slikken en platen in de Oosterschelde $(1990$ - 2019)
}




\section{Ontwikkeling van prooidieren voor steltlopers van slikken en platen in de Oosterschelde (1990 - 2019)}

Auteur(s): J.A. Craeymeersch, T. Ysebaert

Dit onderzoek is uitgevoerd door Wageningen Marine Research en gesubsidieerd door het Ministerie van Landbouw, Natuur en Voedselkwaliteit, in het kader van het Beleidsondersteunend onderzoekthema 'Natuurambitie Grote Wateren' (projectnummer BO-43-021.03-001 )

Wageningen Marine Research

Yerseke, september 2021

VERTROUWELIJK Nee

Wageningen Marine Research rapport C071/21 
Keywords: benthos, Oosterschelde, trends

Opdrachtgever: Ministerie van Landbouw, Natuur en Voedselkwaliteit

T.a.v.: Jip van Peijpe

Bezoudenhoutseweg 73

2594 AC Den Haag

BO-43-021.03-001BO-43-021.03-001

Dit rapport is gratis te downloaden van https://doi.org/10.18174/554052

Wageningen Marine Research verstrekt geen gedrukte exemplaren van rapporten.

Wageningen Marine Research is ISO 9001:2015 gecertificeerd.

(C) Wageningen Marine Research

Wageningen Marine Research, instituut binnen de rechtspersoon Stichting Wageningen Research, hierbij vertegenwoordigd door Drs.ir. M.T. van Manen, directeur bedrijfsvoering

KvK nr. 09098104, WMR BTW nr. NL 8113.83.696.B16. Code BIC/SWIFT address: RABONL2U IBAN code: NL 73 RABO 0373599285
Wageningen Marine Research aanvaardt geen aansprakelijkheid voor gevolgschade, noch voor schade welke voortvloeit uit toepassingen van de resultaten van werkzaamheden of andere gegevens verkregen van Wageningen Marine Research. Opdrachtgever vrijwaart Wageningen Marine Research van aanspraken van derden in verband met deze toepassing.

Alle rechten voorbehouden. Niets uit deze uitgave mag weergegeven en/of gepubliceerd worden, gefotokopieerd of op enige andere manier gebruikt worden zonder schriftelijke toestemming van de uitgever of auteur. 


\section{Inhoud}

Samenvatting

$1 \quad$ Inleiding

$2 \quad$ Materiaal en methoden $\quad 7$

$\begin{array}{lll}2.1 & \text { Data bodemdieren } & 7\end{array}$

2.1.1 Beschrijving van de Monitoring van de Waterkundige Toestand des Lands (MWTL) 7

2.1.2 Beschrijving van de monitoring vanuit Wettelijke Onderzoekstaken (WOT) 10

2.2 Analyses 11

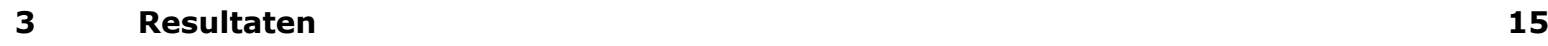

3.1 Data MWTL 15

3.1.1 Ruimtelijke verschillen en temporele veranderingen in dichtheid en biomassa van bodemdiergemeenschappen 15

3.1.2 Ruimtelijke verschillen en temporele veranderingen in biomassa van prooisoorten voor 12 soorten steltlopers $\quad 19$

3.2 Data WOT

4 Discussie $r 2$

4.1 Datasets $\quad 26$

$\begin{array}{lll}4.2 & \text { Trends in benthos } & 27\end{array}$

$\begin{array}{lll}4.3 & \text { Steltlopers en hun prooidieren } & 27\end{array}$

$5 \quad$ Conclusies en aanbevelingen $\quad 31$

$6 \quad$ Kwaliteitsborging $\quad 32$

$\begin{array}{lr}\text { Literatuur } & 33\end{array}$

$\begin{array}{ll}\text { Verantwoording } & 35\end{array}$

Bijlage 1 . Trends in de gemiddelde dichtheid (ind $/ \mathrm{m}^{2} \pm$ standaardfout) van een aantal bodemdieren in de vier deelgebieden van de Oosterschelde (MWTL; 1992-2017 met uitzondering van 2015 en 2016, deelgebied Midden vanaf 2009)

Bijlage 2 . Trends in de gemiddelde biomassa (gAFDW $/ \mathrm{m}^{2} \pm$ standaardfout) van een aantal bodemdieren in de vier deelgebieden van de Oosterschelde (MWTL; 1992-2017 met uitzondering van 2015 en 2016, deelgebied Midden vanaf 2009) 


\section{Samenvatting}

Het verdwijnen van de droogvallende platen en slikken in de Oosterschelde als gevolg van de zandhonger zorgt voor een algehele kwaliteitsvermindering van het habitattype H1160 (grote baaien) voor Nederland. De steltlopers zijn van de droogvallende platen en slikken afhankelijk voor hun voedsel. Het is dus te verwachten dat er een moment komt dat de afname van de bij eb droogvallende gebieden negatief gaat werken op de vogelaantallen (de Ronde et al., 2013). Deze afname zal in de toekomst nog versterkt worden door de zeespiegelstijging. $\mathrm{Er}$ is uiteraard een direct effect op vogelaantallen te verwachten door het verdwijnen van de platen (vermindering foerageerareaal). Maar ook indirect kan er een effect zijn doordat nog aanwezige platen minder lang droogvallen, en er dus minder tijd is voor steltlopers om er te foerageren (verkorten foerageertijden). Of omdat deze morfologische veranderingen in de hydrodynamische omstandigheden en de geomorfologie een invloed kunnen hebben op het bodemleven zelf (soortensamenstelling, ecologische rijkdom). Dat zou misschien wel tot een verminderd voedselaanbod kunnen leiden.

Zo'n 10 jaar geleden is de stand van zaken m.b.t. deze aspecten samengevat in een de rapportage Algemene Neerwaartse Trend Oosterschelde (ANT) (Troost and Ysebaert 2011). Recent is een update gemaakt van de stand van zaken m.b.t. de steltlopers (van Donk et al., 2020) en de verwachte morfologische ontwikkelingen van litorale platen en slikken bij zeespiegelstijging (Zandvoort et al., 2019). In voorliggende rapportage zijn in het kader van beleidsondersteunend onderzoek in opdracht van het ministerie van Landbouw, Natuur en Voedselkwaliteit trends van dichtheden en biomassa's van bodemdieren geanalyseerd over een periode van 1990 tot 2019 om te bepalen hoe individuele prooisoorten alsook het totale voedselaanbod voor steltlopers, uitgedrukt in aantallen en biomassa per vierkante meter, zich in die periode ontwikkeld hebben. Troost en Ysebaert (2011) rapporteerden dat met name in de Kom (Oost) er in de periode 1990 - 2007 een afname was van het areaal met een droogvalduur van 40-60\%. Aan de hand van de droogvalduurkaarten door RWS gemaakt ten behoeve van updates van de ecotopenkartering is nagegaan of deze trend zich verdergezet heeft. Dat blijkt niet het geval.

Voor de analyses van de bodemdierkarakteristieken zijn gegevens gebruikt van de litorale gebieden in de Oosterschelde, jaarlijks ingewonnen in het kader van MWTL (Monitoring van de Waterkundige Toestand des Lands; 1992-2017) en WOT (Wettelijke Onderzoekstaken schelpdiervisserij; 1990-2019). De prooikeuzes van steltlopers hebben we in deze studie vrij algemeen geselecteerd, op basis van overzicht in Leopold et al (2004), om in ieder geval grote verschillen in prooikeuze te kunnen duiden (bijv. wormen versus tweekleppigen als belangrijkste voedselbron). Het belang van specifieke prooidieren voor een aantal steltlopers in deze studie is mogelijk verkeerd ingeschat, omdat dit per watersysteem en zelfs afhankelijk van het seizoen kan verschillen. Zo noemen Troost en Ysebaert (2011) het wadslakje ( $P$. ulvae) als belangrijke voedselbron voor zilverplevieren, terwijl we er in deze studie vanuit gegaan zijn dat ze vooral borstelwormen eten. Voor zilverplevieren is er de laatste decennia een toename, ondanks een afname van het wadslakje in deze periode. Beschikbaarheid van deze prooisoort heeft dus geen belangrijke rol gespeeld voor de populatie zilverplevieren.

Concluderend kunnen we stellen dat ondanks de veranderingen in de MWTL-bemonsteringsstrategie, deze samen met de WOT-data (voor bepaalde soorten) een goed beeld geven over de globale trends van de dichtheid en biomassa van belangrijke prooidieren voor steltlopers in de droogvallende delen (litoraal) van verschillende deelgebieden van de Oosterschelde.

We constateren een daling van het voedselaanbod voor de scholekster en de kanoet, met name kokkels, in de noordelijke tak (deelgebied Noord). Maar ook het voedselaanbod voor de steenloper daalt in dit deelgebied, vooral te wijten aan de afname van wadslakjes. Ook in de Kom (deelgebied Oost) lijkt de trend van prooien voor meerdere soorten (o.a. steenloper, groenpootruiter, zwarte ruiter, tureluur) voor een groot deel bepaald door de trend van wadslakjes. Het voedselaanbod was daar maximaal rond de eeuwwisseling. De veranderingen in dichtheid en biomassa van andere prooidiersoorten, evenals van het totale aanbod aan prooidieren voor andere steltlopers, vertonen geen duidelijke trends. 
Benadrukt moet worden dat de resultaten geen volledig beeld geven van de veranderingen in voedselaanbod, want dat wordt niet alleen bepaald door de gemiddelde dichtheid en biomassa aan prooidieren. Want het aanbod van prooidieren voor steltlopers wordt ook bepaald door het areaal intergetijdengebied en de verdeling van de bij eb droogvallende gebieden over verschillende droogvalduurklasses. Deze laatste heeft zowel invloed op de bodemdieren zelf, als op de beschikbare tijd voor steltlopers om in de gebieden met de hoogste benthische biomassa te foerageren. Zoals hierboven aangegeven, lijkt er het laatste decennium geen verdere achteruitgang van het areaal met de hoogste biomassa aan bodemdieren (droogvalduur $<60 \%$ ). Een goede analyse van de relatie tussen trends van steltlopers en bodemdieren, vereist daarom ook voldoende data over veranderingen in de droogvalduur.

De vraag is ook of de beschikbare informatie over de aantallen steltlopers en de bodemdieren wel voldoende is om oorzaken van veranderingen in aantallen steltlopers te kunnen inschatten, en of er een verband is met de zandhonger, direct (via veranderingen in plaatareaal en droogvalduur) of indirect (via veranderingen in het benthos). De gegevens over bodemdieren uit het MWTL-programma geven wel een algemeen beeld over de trends in de Oosterschelde en de vier deelgebieden, maar waarschijnlijk onvoldoende nauwkeurig over de exacte delen van de platen waar steltlopers foerageren. De vogels worden binnen het MWTL-programma geteld op hoogwatervluchtplaatsen, en geven dus geen informatie over het gebruik van droogvallende platen en slikken. Ook de informatie over de veranderingen in het benthos binnen deelgebieden is op basis van het MWTL-programma naar verwachting beperkt, omdat het aantal monsters op die plekken waar steltlopers foerageren waarschijnlijk zeer klein is . Enkel laagwatervogeltellingen kunnen een beeld geven over waar steltlopers foerageren en - gecombineerd met gedetailleerde informatie over bodemdieren en abiotische omstandigheden waaronder droogvalduur - waarom ze op bepaalde plaatsen voorkomen (los van verstoringen), zoals lopende in de Westerschelde. Zo'n studie naar de morfologische ontwikkelingen, bodemdieren (voedselaanbod en kwaliteit) en gebruik door steltlopers gebeurt momenteel wel op de Roggenplaat (Ysebaert et al., 2016b). Wellicht kunnen de komende resultaten uit die studie een beter beeld geven of de uit MWTL en WOT beschikbare informatie over bodemdieren en steltlopers voldoende is en, zo niet, welke aanvullende informatie nodig is om te kunnen inschatten of veranderingen in aantallen steltlopers al of niet verband houden met de zandhonger. 


\section{$1 \quad$ Inleiding}

De sterke afname van de hoeveelheid water die per getij de Oosterschelde in- en uitstroomt, was na de realisatie van de Deltawerken niet meer in balans et de doorsnede van de geulen. Het gevolg hiervan ins een netto afbraak van de hoge platen en slikken waarbij het van de platen en slikken vrijkomende sediment bezinkt in de geulen. Dit proces wordt 'zandhonger' genoemd (Jacobse et al., 2008).

Door erosie van platen en slikken neemt het totale areaal af en hebben vogelsoorten die bodemdieren eten (steltlopers) steeds korter de tijd om te kunnen foerageren als deze gebieden met laag water droogvallen (Troost and Ysebaert 2011). Voor de betekenis van deze gebieden als foerageergebied zijn zowel het voedsel (bodemdieren) als de droogvalduur van belang. Deze laatste bepaalt hoe lang steltlopers de tijd hebben om te foerageren. Daarenboven is de benthische biomassa ook het hoogst bij een droogvalduur lager dan 60\% (Troost and Ysebaert 2011). Om (veranderingen) in aantallen steltlopers te kunnen begrijpen, is inzicht nodig in het voedselaanbod. Dit aanbod wordt bepaald door de tijd dat slikken en platen droogvallen (de droogvalduur) en het voorkomen en de beschikbaarheid van bodemdieren die de prooidieren vormen voor deze vogelgroep. Karakteristieken van de litorale bodemdiergemeenschappen - zoals soortensamenstelling, biodiversiteit en ecologische waarde - worden beïnvloed door veranderingen in geomorfologie en hydrodynamische omstandigheden (Thrush et al., 2004; Ysebaert et al., 2016a).

In de studie van Troost and Ysebaert (2011) zijn de lange-termijnontwikkelingen van 1987 t/m 2010 geanalyseerd. Inmiddels zijn we een kleine 10 jaar verder. In het huidige rapport wordt een update gegeven van Troost and Ysebaert (2011) waarbij opnieuw gekeken wordt naar de ontwikkelingen van de bodemdieren. Een update over de veranderingen in de vogelaantallen is recent gerapporteerd door (van Donk et al., 2020). Omdat de droogvalduur niet alleen van belang is voor de steltlopers, maar ook van direct van belang is voor de hoeveelheid bodemdieren (biomassa), besteden we ook aandacht aan de ontwikkeling van de morfologie. . Troost and Ysebaert (2011) rapporteren de veranderingen in arealen met een verschillende droogvalduur voor vier deelgebieden in de Oosterschelde, in de periode 1990 - 2007. De voornaamste conclusie was dat met name in de Kom (oostelijk deel) er een afname was van het areaal met een droogvalduur van $40-60 \%$. Het areaal met droogvalduren tussen 0 en $40 \%$ nam toe. In deze studie hebben we nagegaan of deze afname zich verder gezet heeft in latere jaren, en hoe de ontwikkeling was in de andere deelgebieden.

De centrale vragen van deze studie zijn:

- Hoe hebben benthische soorten en voedselgroepen, met name diegene die als voedsel dienen voor steltlopers, zich in de tijd ontwikkeld en zijn er verschillen tussen deelgebieden in de Oosterschelde? Doel is dus om inzicht te verkrijgen in (het verloop van) de waarde van de litorale gebieden in de Oosterschelde, met name m.b.t. de benthische organismen als voedsel voor Natura 2000-steltlopersoortenHoe heeft de morfologie van de getijdenplaten zich verder ontwikkeld: welke veranderingen zijn opgetreden in droogvalduur en oppervlakte en zijn er verschillen tussen deelgebieden in de Oosterschelde?

De resultaten van deze studie over bodemdieren en morfologie kunnen, in combinatie met de rapportage over ontwikkelingen in het steltlopers (van Donk et al., 2020) en de verwachte toekomstige ontwikkeling in het platenareaal (Zandvoort et al., 2019), gebruikt worden om na te gaan in een hoeverre aan de Natura 2000-instandhoudingsdoelen voor kwaliteit en oppervlak habitat van beschermde steltlopersoorten voldaan kan worden. Daarnaast draagt deze kennis direct bij aan de Systeemrapportage Oosterschelde die door samenwerkende partijen Rijkswaterstaat, Deltares en Wageningen Marine Research wordt ontwikkeld. (https://www.testsysteemrapportage.nl/ oosterschelde/). 


\section{Materiaal en methoden}

\section{$2.1 \quad$ Bodemdieren}

$\mathrm{Er}$ is gebruik gemaakt van twee data-bronnen van bodemdieren afkomstig van de monitoringprogramma's MWTL en WOT. Hieronder wordt de (verandering in) methodiek van deze monitoringsprogramma's nader toegelicht.

\subsubsection{Beschrijving van de Monitoring van de Waterkundige Toestand des Lands (MWTL)}

In het kader van het Biologisch Monitoring Programma worden sinds 1990 de bodemdieren bemonsterd in een aantal gebieden in het Deltagebied, waaronder de Oosterschelde, zowel in het litoraal als het sublitoraal. Omdat de wijze van monitoren meerder malen is aangepast en dit ook relevant is voor de bruikbaarheid van de data wordt dit hier nader toegelicht.

Tot 1992 waren er grote verschillen in de bemonsteringsstrategie, ook binnen een enkel watersysteem. Locaties werden of random gekozen, waren vaste locaties of lagen langs transecten. Daarnaast was ook de bemonsteringswijze vaak verschillend, zelfs binnen eenzelfde watersysteem, zeker in het litoraal.

Vanaf 1992 werden alle locaties bij iedere bemonstering random gekozen. In de Oosterschelde betrof dit 10 locaties, in 4 dieptestrata en in 3 deelgebieden. Deze gebieden lagen in het westelijk deel (mondingsgebied), in de noordelijke tak (Keeten-Mastgat-Zijpe) en in het oostelijk deel (kom). Mosselpercelen werden niet meegenomen. De vier dieptestrata waren: eulitoraal, $-2 \mathrm{~m}$ tot $-5 \mathrm{~m}$ t.o.v. NAP, $-5 m$ tot $-8 m$ t.o.v. NAP en dieper dan $8 m$ t.o.v. NAP (Figuur 1). Eulitoraal zijn respectievelijk de zuidelijke helft van de Roggenplaat, de slikken van Viane en een deel van het Verdronken land van ZuidBeveland opgenomen. Er werd bemonsterd in het voorjaar (maart-mei) en het najaar (septemberoktober). In het sublitoraal werd op ieder punt één Reineck box-corer genomen. Hieruit werden telkens drie deelmonsters genomen met een buis van $8 \mathrm{~cm}$ doorsneden. Deze werden samengevoegd tot een monster en aan boord uitgespoeld op een $1 \mathrm{~mm}$-zeef. Analoog werden ook in het eulitoraal drie steekuizen genomen en samengevoegd.

In 1994 werd het programma opnieuw geëvalueerd, via een poweranalyse. Daarbij zijn drie ANOVAmodellen bekeken: het 'geneste' model (ieder jaar nieuwe random punten), het 'mixed' model (eenmaal random gekozen punten worden telkens herbemonsterd) en het 'vaste' model (vast gekozen bemonsteringslocaties worden steeds herbemonsterd). In bijna alle watersystemen bleek het 'mixed' model de hoogste power te hebben (Duin, 1994; van der Meer, 1997), ook in de Deltawateren op de Westerschelde na (Craeymeersch, 1999b). Vanaf 1995 werden daarom steeds dezelfde locaties als in het najaar 1994 herbemonsterd.

Vanaf 2009 is in de Oosterschelde (en Westerschelde) voor een ecotoopgerichte bemonsteringsstrategie gekozen (Escaravage et al., 2010). Daarbij zijn op voorhand een aantal ecotopen gedefinieerd op basis van zoutgehalte, hoogte ligging, dynamiek en slibgehalte. Op basis van een door RWS-Zeeland afgeleverde ecotopenkaart (2001) zijn een aantal ecotopen gekozen om te bemonsteren: vier litorale ecotopen (hoogdynamisch litoraal, laagdynamisch laag litoraal, laagdynamisch midden litoraal, laagdynamisch hoog litoraal) en vier sublitorale ecotopen (diep en ondiep hoogdynamisch, diep en ondiep laagdynamisch). Achteraf bleek dat in ZES.1 geen onderscheid gemaakt is tussen de twee dieptestrata binnen het hoogdynamisch sublitoraal (Escaravage et al., 2011), en is dit onderscheid komen te vervallen. Binnen elk ecotoop zijn, verspreid over de hele Oosterschelde, at random een vooraf 
gesteld aantal monsterpunten toegekend: 80 punten in het litoraal en 50 punten in het sublitoraal. Vanaf 2009 vond enkel in het najaar een bemonstering plaats.

In 2009 werden, zoals voorheen, op iedere locatie 3 monsters met een steekbuis van $8 \mathrm{~cm}$ doorsnede genomen, in het sublitoraal uit een box-corer. Vanaf 2010 is dit aangepast: 2 steekbuizen van $10 \mathrm{~cm}$ doorsnede. Vanaf 2013 is in het sublitoraal de hele box-corer uitgespoeld.

In 2014 is het onderscheid tussen het laagdynamisch hoog en laagdynamisch midden litoraal komen te vervallen, en zijn deze samengevoegd tot laagdynamisch midden litoraal. Ook in het laagdynamisch sublitoraal is geen onderscheid meer gemaakt tussen diep en ondiep (Verduin et al., 2015). In totaal werden 50 locaties bemonsterd in het sublitoraal en 75 in het litoraal.

In 2015 is in de Oosterschelde niet gemonsterd, in 2016 enkel sublitoraal (Verduin et al., 2018). In 2017 is weer gemonsterd als in 2014 (Duijts et al., 2018).

Tijdens het veldwerk wordt nagegaan of de geplande locatie wel in het beoogde ecotoop ligt. Immers, de ecotopenkaarten worden niet ieder jaar gemaakt en dus kunnen er zich lokaal veranderingen voorgedaan hebben. Als het niet mogelijk was om binnen de $100 \mathrm{~m}$ van een beoogde locatie het verwachte ecotoop te bemonsteren, werd toch op de geplande locatie een monster genomen en het ecotoop beschreven (Escaravage et al., 2011; Leewis et al., 2015). Dit kon, uiteraard, enkel bij de litorale ecotopen want bij de sublitorale monsters is het niet mogelijk om (behalve aan de hand van de diepte) te controleren of de monsterlocatie daadwerkelijk aan het geplande ecotoop voldeed. Zeker in de eerste jaren lagen veel monsterlocaties niet in het geplande ecotoop (bijv. 30 in 2010). Later lag dit aantal lager (bijv. 4 in 2014).

Meestal is in de centrale dataset zowel het beoogde ecotoop als het gerealiseerde ecotoop terug te vinden, respectievelijk als onderdeel van het donarnummer (bijv. OSZHDL11: Oosterschelde, Zout, Hoogdynamisch), of bij de beschrijving (dynamiek, hoogteligging,...). In 2014 waren er echter 5 locaties beoogd in het hoogdynamisch litoraal, maar in de beschrijving is enkel laagdynamisch opgenomen zonder hoogteligging. Meest waarschijnlijk is dat deze in het aangelegen laag litoraal lagen, en dit hebben we bij de verwerking ook als zodanig 'gecorrigeerd'.

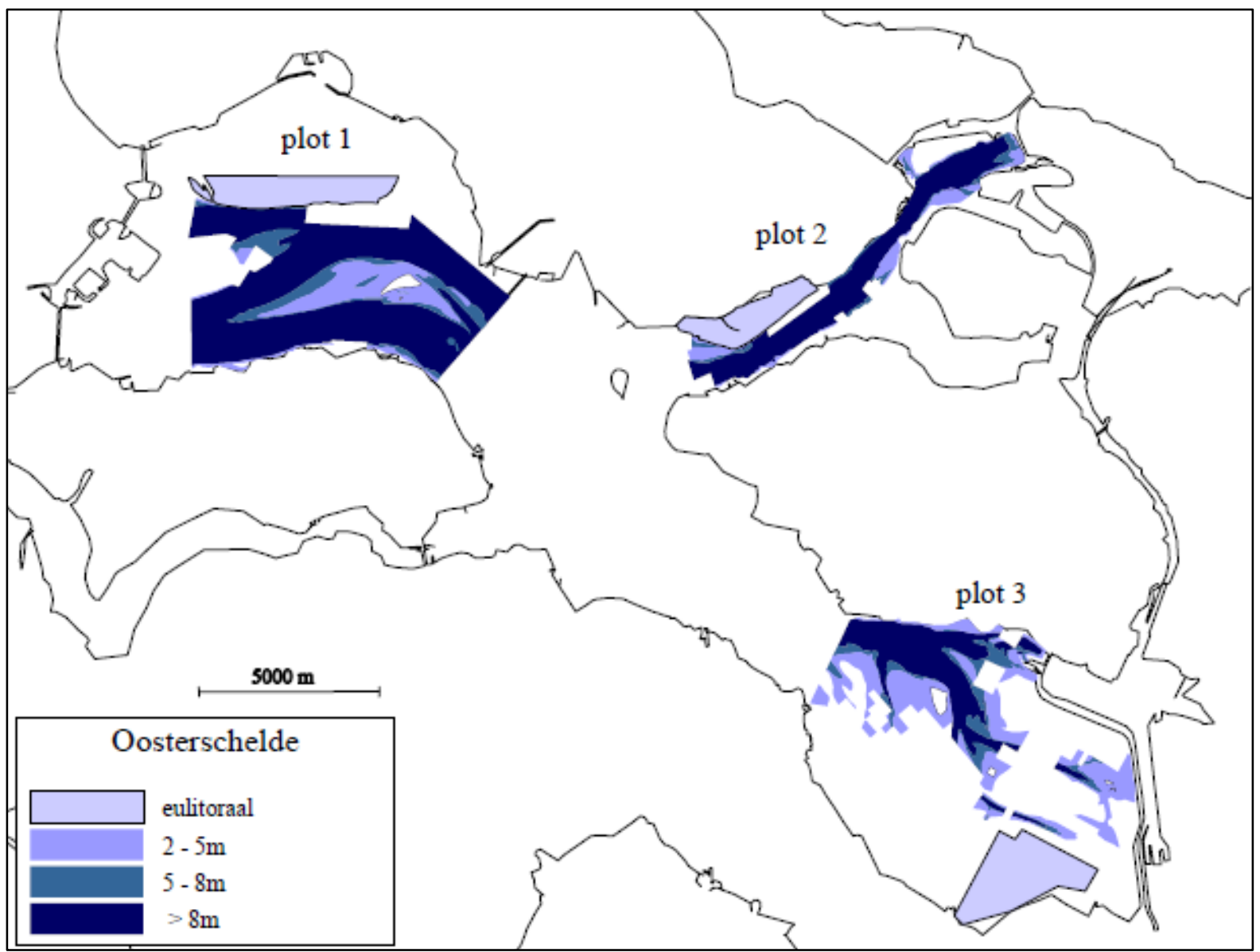

Figuur 1. Ligging en diepteverdeling van de drie deelgebieden in de Oosterschelde zoals bemonsterd in de periode 1992-2008 (Sistermans et al., 2009) 


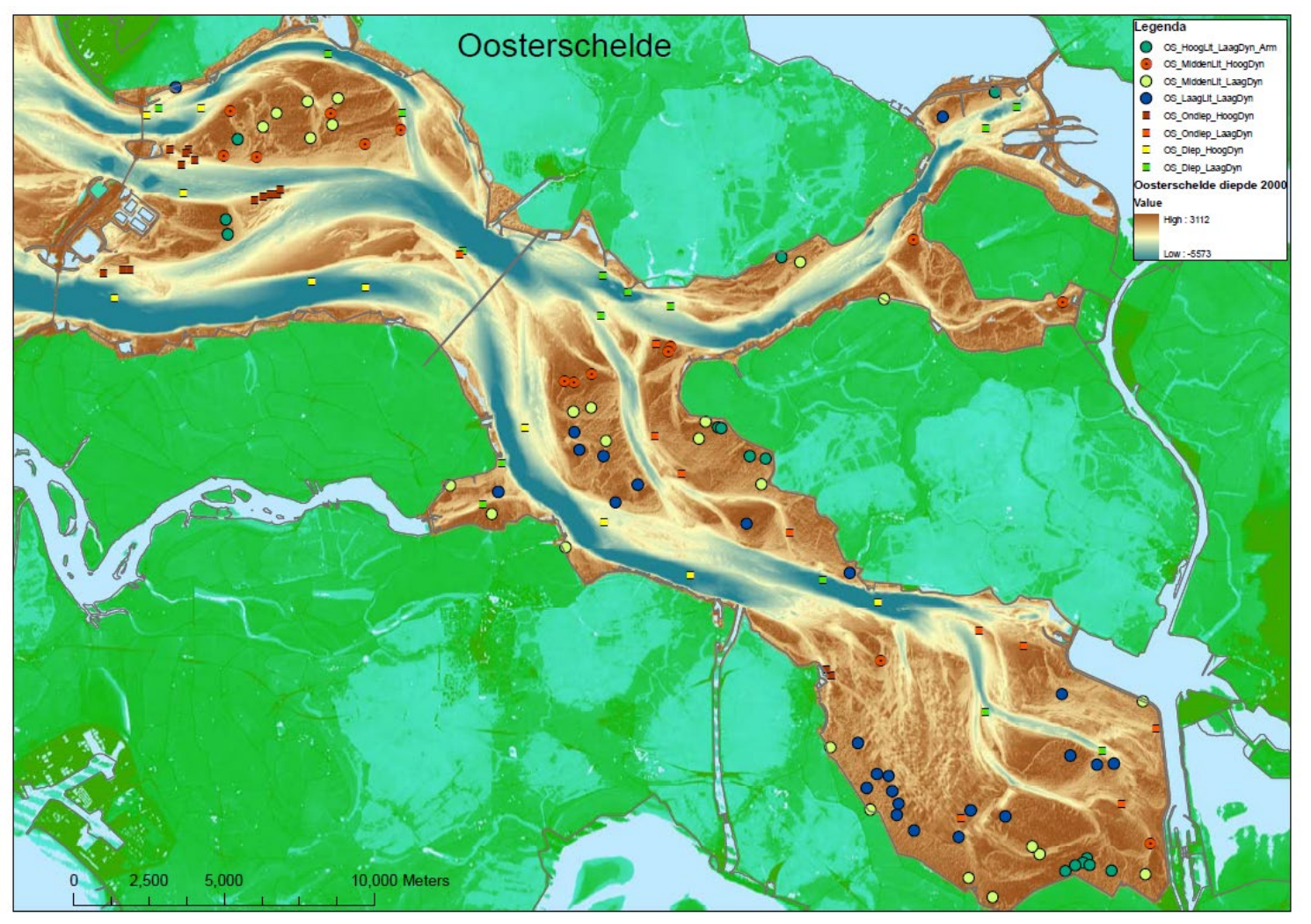

Figuur 2. Bemonsterde ecotopen in de Oosterschelde in 2009 (Escaravage et al., 2010)

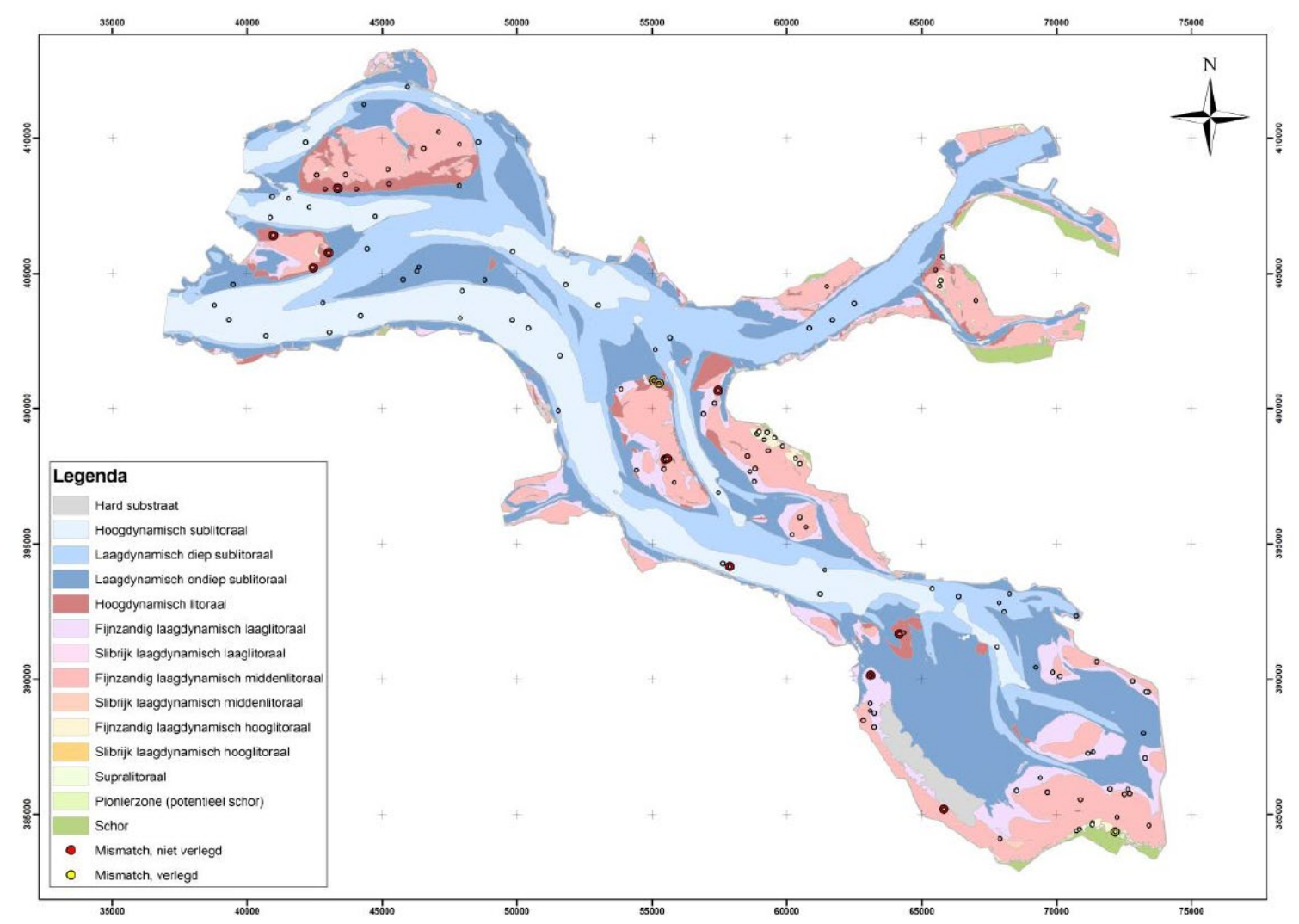

Figuur 3. Ligging van de monsterpunten in de Oosterschelde in 2013. Punten gemarkeerd met geel zijn tijdens de survey verlegd en dus in het beoogde ecotoop. Punten gemarkeerd met rood zijn niet verlegd maar vielen niet in het beoogde ecotoop (Leewis et al., 2015) 


\subsubsection{Beschrijving van de monitoring vanuit Wettelijke Onderzoekstaken (WOT)}

Sinds 1990 wordt het bestand aan kokkels in de Oosterschelde geïnventariseerd. Deze inventarisatie vindt in het voorjaar plaats en wordt uitgevoerd door Wageningen Marine Research (WMR) onder het wettelijke taken programma Visserijonderzoek en gefinancierd door het Ministerie van Landbouw, Natuur en (LNV). Doel van de inventarisaties is een bepaling van het totale litorale kokkelbestand. Er wordt in principe gebiedsdekkend gemonsterd, dus ook in gebieden die geheel of gedeeltelijk gesloten zijn voor visserij. Deze inventarisatie wordt jaarlijks uitgevoerd om te kunnen bepalen hoeveel kokkels opgevist mogen worden en is daarnaast ook van belang voor evaluatie van beheersmaatregelen en effectstudies in het kader van bijvoorbeeld Natura 2000 en de Wet Natuurbescherming.

Het litoraal wordt volledig gedekt tijdens de bemonstering. In de Oosterschelde liggen de monsterlocaties op raaien die 0,5 geografische minuten (ca. 555 meter) uit elkaar liggen. De onderlinge afstand tussen de monsterpunten op een raai bedraagt 0,25 geografische minuut ( $=463$ meter in NoordZuid richting) (Figuur 4).

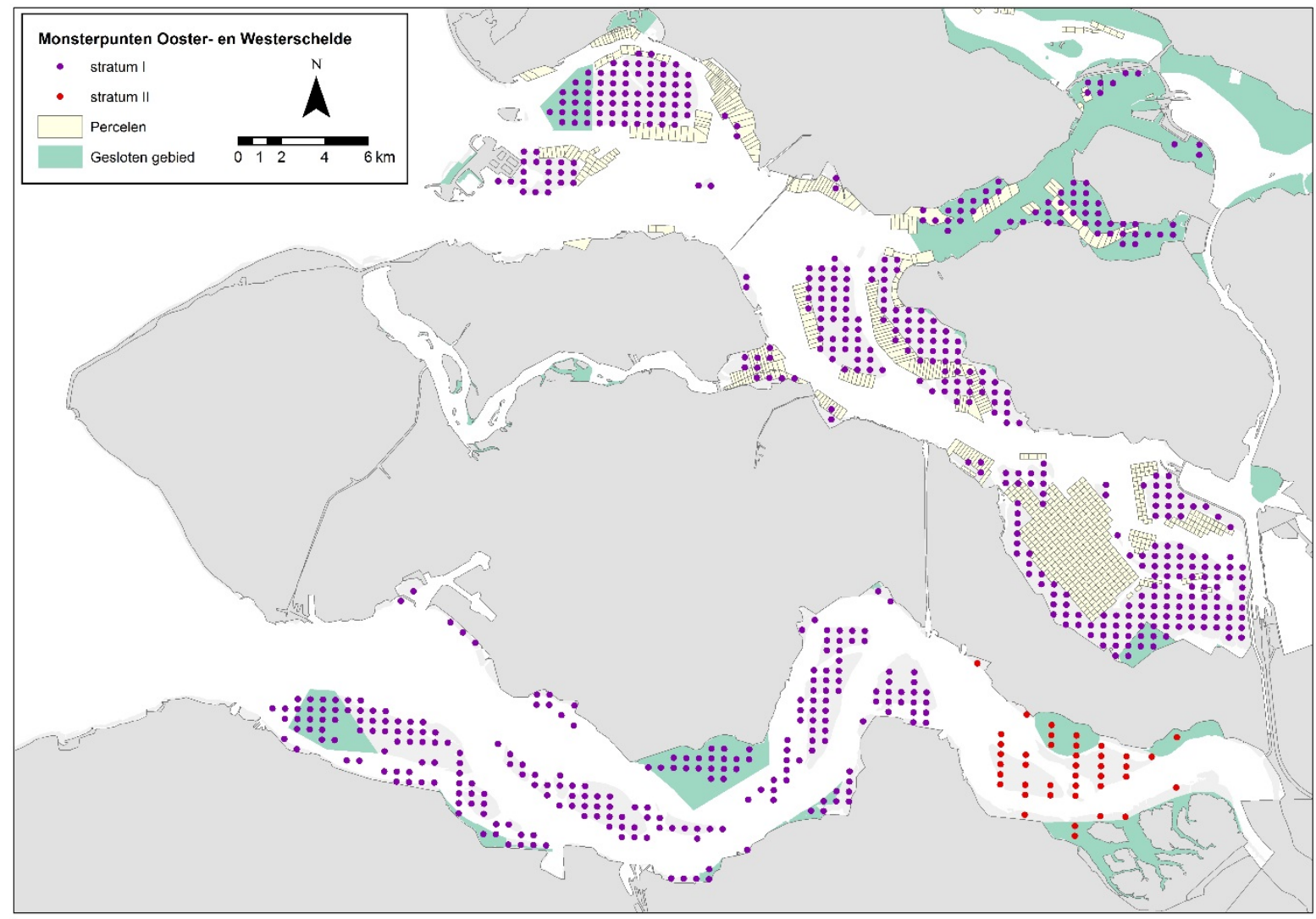

Figuur 4. De tijdens de kokkelinventarisatie bemonsterde litorale stations in de Oosterschelde (en Westerschelde) (van Asch et al., 2019) 
In de Oosterschelde wordt op twee manieren gemonsterd. De hooggelegen punten worden bemonsterd met een steekbuis (doorsnede $24.4 \mathrm{~cm}$; diepte $7 \mathrm{~cm}$ ). Er worden 2 monsters per punt genomen (totaal bemonsterd oppervlak $0,1 \mathrm{~m}^{2}$ ). De overige monsters worden genomen met een zogenaamd kokkelschepje (Figuur 5). Hiermee worden per locatie 3 monsters uit de bodem gestoken die als één worden behandeld (totaal bemonsterd oppervlak $0,1 \mathrm{~m}^{2} ; 7 \mathrm{~cm}$ diep). Naast kokkels worden ook de andere dieren, voornamelijk schelpdieren, op naam gebracht, geteld en gewogen.

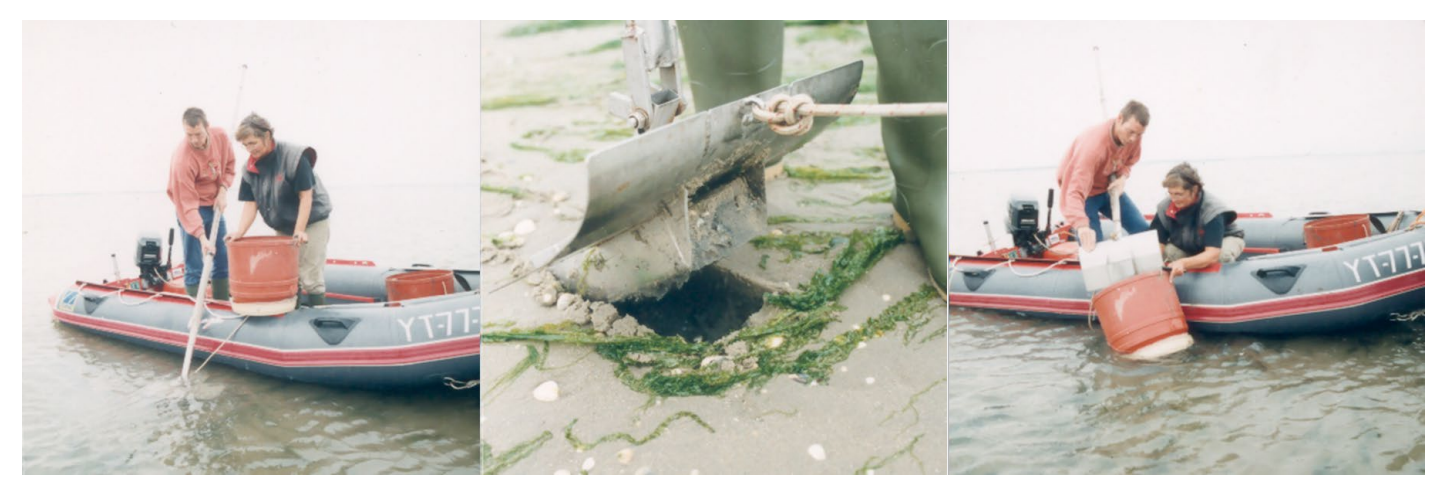

Figuur 5. Bemonstering met het kokkelschepje

\subsubsection{Analyses}

Op basis van de najaarsdata van litorale locaties in beide datasets (MWTL en WOT; zie hierboven) zijn analyses uitgevoerd van:

- $\quad$ De totale dichtheid en biomassa aan bodemdieren (data MWTL)

- De totale dichtheid en biomassa van een aantal hogere taxonomische niveaus: tweekleppigen (Bivalvia), slakken (Gastropoda), borstelwormen (Annelida) en kreeftachtigen (Arhropoda) (data MWTL)

- De dichtheid en biomassa van een aantal specifieke soorten, soorten die ook in Troost and Ysebaert (2011) speciale aandacht kregen: de kokkel (Cerastoderma edule), het nonnetje (Limecola balthica), de wadpier (Arenicola marina), het kniksprietkreeftje (Bathyporeia sp.), (Corophium arenarium), garnalen (Crangon sp.), vlokreeften van het genus Gammarus (Gammarus sp.), de veelkleurige zeeduizendpoot (Hediste diversicolor), de draadworm (Heteromastus filiformis), de schelpdierkokerworm (Lanice conchilega), de zandzager (Nephtys hombergii), het zandkokerwormpje (Pygospio elegans), de wapenworm (Scoloplos armiger) en het wadslakje (Peringia ulvae) (data MWTL en, voor kokkel en nonnetje ook WOT).

- De totale biomassa aan geschikte prooidieren voor een aantal specifieke steltlopers, gebaseerd op hun dieet (data MWTL).

Niet alle steltlopers eten alle en dezelfde soorten bodemdieren. Om het voedselaanbod voor de verschillende soorten steltlopers te bepalen, is het nodig om selecties van de bodemdieren te maken, afhankelijk van de beschouwde soort. Vaak is een expertenoordeel nodig om het belang van verschillende prooisoorten (tweekleppigen, wormen, kreeftachtigen, ...) te duiden. In deze studie is dezelfde methodiek gebruikt als recent gedaan in de Westerschelde (Craeymeersch et al., 2020). Hierbij worden bodemdieren in drie klassen verdeeld (tweekleppigen, wormen en overige dieren) en is aangegeven hoe belangrijk iedere klasse is (Tabel 1). De biomassa aan prooidieren voor de scholekster bijvoorbeeld is berekend als de som van $80 \%$ van de biomassa aan tweekleppigen, $10 \%$ van de biomassa aan wormen en $10 \%$ van de biomassa aan overige bodemdieren. Met dit algemene beeld ondervangen we in ieder geval grote verschillen in prooikeuzes, bijv. wormen versus tweekleppigen als hoofdvoedsel. 
Conform eerdere studies zijn de analyses uitgevoerd voor vier deelgebieden: West, Midden, Oost en Noord (Figuur 6).

Tabel 1. Procentuele verdeling van prooidieren van steltlopers, verdeeld in tweekleppigen, wormen en overige soorten (Leopold et al., 2004)

\begin{tabular}{|l|c|c|c|}
\hline Soort & $\begin{array}{c}\text { Tweekleppigen } \\
(\mathbf{\%})\end{array}$ & $\begin{array}{c}\text { Wormen } \\
(\mathbf{\%})\end{array}$ & $\begin{array}{c}\text { Overige } \\
(\mathbf{\%})\end{array}$ \\
\hline Scholekster & 80 & 10 & 10 \\
\hline Kanoet & 75 & 1 & 24 \\
\hline Rosse Grutto & 3 & 94 & 3 \\
\hline Kluut & 5 & 90 & 5 \\
\hline Zilverplevier & 6 & 87 & 7 \\
\hline Bontbekplevier & 0 & 78 & 22 \\
\hline Bonte Strandloper & 14 & 70 & 16 \\
\hline Drieteenstrandloper & 1 & 60 & 39 \\
\hline Wulp & 46 & 35 & 19 \\
\hline Tureluur & 7 & 46 & 47 \\
\hline Groenpootruiter & 0 & 10 & 90 \\
\hline Steenloper & 20 & 5 & 75 \\
\hline Zwarte Ruiter & 4 & 34 & 62 \\
\hline
\end{tabular}

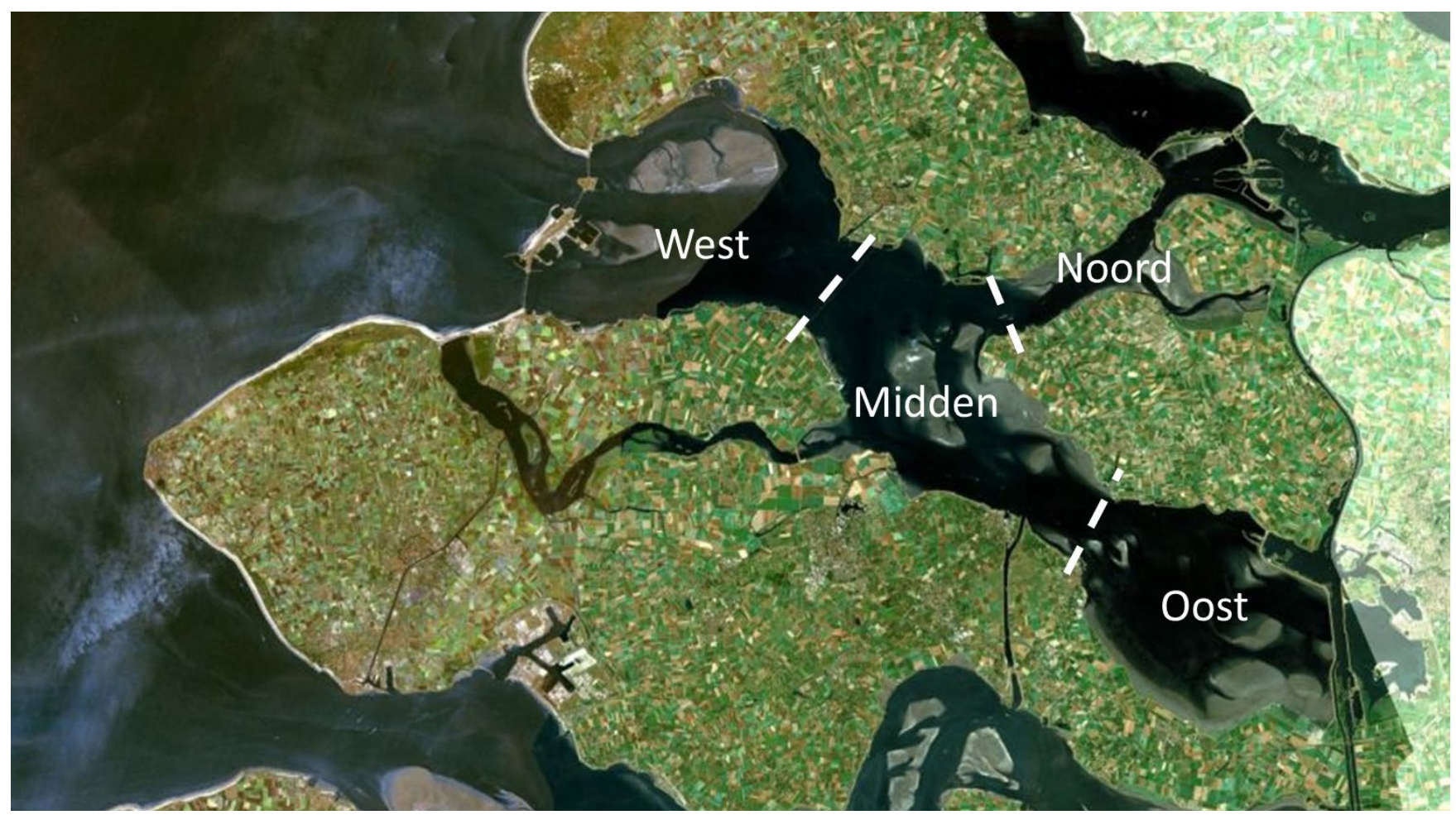

Figuur 6. Ligging van de vier deelgebieden in de Oosterschelde.

We focussen de analyses op het litoraal omdat dit de droogvallende gebieden zijn waar steltlopers foerageren. Zoals aangegeven in paragraaf 2.1.1, is de bemonsteringsstrategie MWTL in de loop der jaren gewijzigd. Vanaf 2009 is in het litoraal gestratificeerd naar ecotopen, en vanaf 2014 beperkt tot 3 ecotopen: hoogdynamisch litoraal, laagdynamisch laag litoraal, en laagdynamisch midden litoraal (inclusief hoog litoraal). We hebben per deelgebied de gemiddelde waardes voor de jaren $2009 \mathrm{t} / \mathrm{m}$ 2017 daarom op 2 manieren berekend:

- $\quad$ Rekenkundig gemiddelde van alle locaties in het litoraal;

- $\quad$ Een gemiddelde gewogen naar het oppervlakte van de ecotopen.

Er bleken geen opvallende verschillen tussen de twee rekenmethodes. Dat komt omdat de meeste locaties in het midden laagdynamisch litoraal lagen (Tabel 2), en dit ecotoop ook de grootste oppervlakte heeft (Tabel 3). Dat was ook al zo in de periode 1992-2008, toen er nog geen onderscheid in ecotopen 
gemaakt werd bij de planning en uitvoering. Maar Bij controle (overlay locaties in die periode en ecotopenkaart) blijkt dat ook in deze periode de meeste locaties in het midden laagdynamisch litoraal lagen. Daardoor kunnen we de tijdreeks opmaken voor de hele studieperiode, a.h.v. gemiddelde waardes per deelgebied. In de periode 1992-2008 zijn geen monsters genomen in het centrale deel van de Oosterschelde (deelgebied Midden).

Tabel 2. Aantal bemonsterde locaties per ecotoop per deelgebied in de periode 2009-2017 in het litoraal

\begin{tabular}{|c|c|c|c|c|c|c|c|c|}
\hline & & 2009 & 2010 & 2011 & 2012 & 2013 & 2014 & 2017 \\
\hline \multirow[t]{4}{*}{ West } & hoogdynamisch & 2 & 3 & 7 & 8 & 3 & 3 & 11 \\
\hline & laagdynamisch laag & 1 & 4 & 2 & 2 & 0 & 3 & 2 \\
\hline & laagdynamisch midden & 13 & 10 & 10 & 5 & 10 & 7 & 5 \\
\hline & & 16 & 17 & 19 & 15 & 13 & 13 & 18 \\
\hline \multirow[t]{4}{*}{ Noord } & hoogdynamisch & 0 & 0 & 0 & 1 & 1 & 0 & 0 \\
\hline & laagdynamisch laag & 1 & 0 & 3 & 4 & 1 & 6 & 1 \\
\hline & laagdynamisch midden & 6 & 10 & 8 & 8 & 4 & 6 & 13 \\
\hline & & 7 & 10 & 11 & 13 & 6 & 12 & 14 \\
\hline \multirow[t]{4}{*}{ Midden } & hoogdynamisch & 0 & 3 & 2 & 0 & 3 & 3 & 3 \\
\hline & laagdynamisch laag & 7 & 5 & 4 & 8 & 7 & 8 & 9 \\
\hline & laagdynamisch midden & 18 & 16 & 20 & 15 & 17 & 6 & 8 \\
\hline & & 25 & 24 & 26 & 23 & 27 & 17 & 20 \\
\hline \multirow[t]{4}{*}{ Oost } & hoogdynamisch & 2 & 0 & 2 & 3 & 2 & 4 & 1 \\
\hline & laagdynamisch laag & 14 & 15 & 13 & 13 & 16 & 15 & 13 \\
\hline & laagdynamisch midden & 14 & 14 & 8 & 13 & 16 & 17 & 9 \\
\hline & & 30 & 29 & 23 & 29 & 34 & 36 & 23 \\
\hline
\end{tabular}

Tabel 3. Oppervlakte per ecotoop per deelgebied, en percentueel aandeel in litoraal (jaar 2016)

\begin{tabular}{|l|l|c|c|}
\hline & & areaal $(\mathrm{km} 2)$ & percentage \\
\hline Midden & hoogdynamisch & 1.70 & 5.95 \\
\hline & laagdynamisch laag & 8.19 & 28.59 \\
\hline & laagdynamisch midden & 18.75 & 65.47 \\
\hline Noord & hoogdynamisch & 1.26 & 8.01 \\
\hline & laagdynamisch laag & 2.69 & 17.08 \\
\hline Oost & laagdynamisch midden & 11.81 & 74.91 \\
\hline & hoogdynamisch & 0.95 & 2.93 \\
\hline \multirow{2}{*}{ West } & laagdynamisch laag & 12.22 & 37.49 \\
\hline & laagdynamisch midden & 19.43 & 59.58 \\
\hline & hoogdynamisch & 3.76 & 17.91 \\
\hline & laagdynamisch laag & 3.27 & 15.58 \\
\hline & laagdynamisch midden & 13.95 & 66.51 \\
\hline
\end{tabular}

\subsection{Droogvalduur}

Troost and Ysebaert (2011) berekenden voor de jaren 1990, 2001 en 2007 de arealen voor een aantal droogvalduurklassen op basis van de arealen voor verschillende hoogteklassen zoals gerapporteerd door Jacobse et al. (2008). De relatie tussen hoogteligging en droogvalduur werd berekend via een polynomiale vergelijking waarvan de parameters geschat werden uit metingen langs transecten (RTKprofielen). Andere parameters golden voor drie dieptezones: $<100 \mathrm{~cm}$ t.o.v. NAP, -100 tot $100 \mathrm{~cm}$ t.o.v. NAP en $>+100$ t.o.v. NAP.

Toepassing van deze formules voor het jaar 2010 leverden een irrealistisch beeld op: arealen met droogvalduur tussen 50 en $80 \%$ waren toegenomen. Kortom, omrekening van de hoogteklassen naar 
droogvalduren kon niet langer via deze formule. Wel beschikten we over droogvalduurkaarten voor de jaren 2001, 2010 en 2016, gemaakt voor het updaten van de ecotopenkaarten (ref). De methodiek waarop de droogvalduur hierbij wordt berekend (Kers et al., 2013), is niet dezelfde als gevolgd door Troost en Ysebaert (2011) en daardoor zijn de resultaten ook niet samen in een enkele tijdsreeks te gebruiken. Wel zijn ze ieder afzonderlijk 'correct' (de Vet, mond. med.). Daarom hebben we ons in dit rapport beperkt tot een vergelijking van de jaren 2001, 2010 en 2016 . Wel hebben we dezelfde droogvalduurklassen aangehouden. 


\section{Resultaten}

\subsection{Bodemdieren}

\subsubsection{Data MWTL}

\subsubsection{Ruimtelijke verschillen en temporele veranderingen in dichtheid en biomassa van bodemdiergemeenschappen}

Het verloop in de tijd van de totale dichtheid en de totale biomassa van bodemdieren is gegeven in Figuur 7. Het verloop van de totale dichtheid en biomassa van een aantal hogere taxa - geleedpotigen (Arthropoda), tweekleppigen (Bivalvia), slakken (Gastropoda), en borstelwormen (Annelida) - is gegeven in Figuur 8 en Figuur 9. Trends van de gemiddelde dichtheid en biomassa van een aantal geselecteerde genera en soorten zijn gegeven in bijlages 1 en 2 . Zoals in eerdere studies geconstateerd (Troost and Ysebaert, 2011), vertonen zowel de totale dichtheid als de totale biomassa grote fluctuaties.

De hoogste totale dichtheden worden in Oost gevonden. De fluctuaties in de totale dichtheid worden in Noord, Midden en Oost veroorzaakt door fluctuaties van Gastropoda (Figuur 8) en met name het wadslakje (Peringia ulvae) met 'record'-hoogtes rond de eeuwwisseling in Oost. In West wordt de totale dichtheid vooral bepaald door de dichtheden van borstelwormen, gevolgd door deze van kreeftachtigen. Verschillende soorten borstelwormen hebben in West regelmatig heel hoge dichtheden, bijv. de veelkleurige zeeduizendpoot (Hediste diversicolor, vooral in eerste jaren), de rode draadworm (Heteromastus filiformis), de schelpkokerworm (Lanice conchilega), de zandzager (Nephtys hombergii) en de wapenworm (Scoloplos armiger). De hoogste dichtheden van S. armiger worden in West gevonden. Lanice conchilega wordt praktisch niet in Oost gevonden. De hoogste dichtheden van de wadpier (Arenicola marina) worden dan weer in Oost gevonden. Heteromastus filiformis heeft ook regelmatig een hoge dichtheid in Noord. Hoge dichtheden van Arthropoda worden vaak veroorzaakt door hoge dichtheden van de slijkgarnaal Corophium arenarium, of van vlokreeftjes als Gammarus sp. en Bathyporeia sp. Deze laatste komt enkel in hogere dichtheden voor in West.

De fluctuaties in de totale biomassa worden in alle deelgebieden vooral bepaald door fluctuaties in de biomassa van Bivalvia (Figuur 9) en met name van de kokkel (Cerastoderma edule). In Noord lijkt er sprake van een afname over de studieperiode. De biomassa van een andere belangrijke soort, het nonnetje (Limecola balthica) heeft geen duidelijke trend. De biomassa van soorten borstelwormen volgt meestal de trend van de dichtheid. Bij Arenicola marina lijkt de biomassa in Oost veelal hoger dan in de andere deelgebieden. Enkel in Noord is er de laatste jaren sprake van een hogere biomassa van de wadpier in vergelijking met eerdere jaren. 

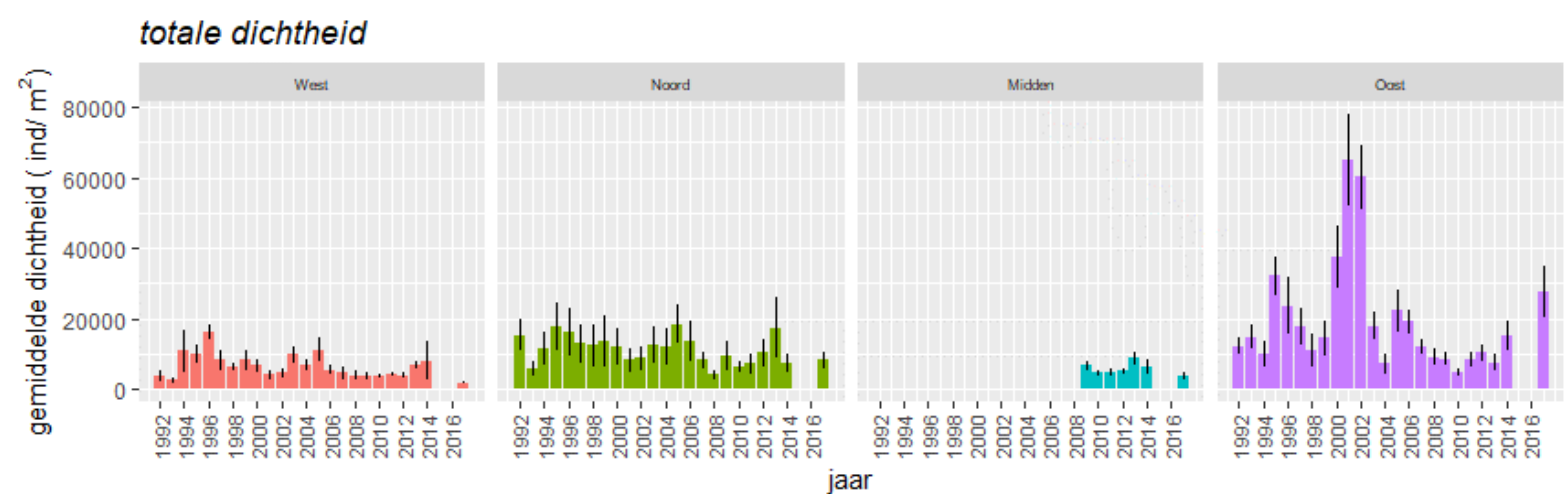

totale biomassa
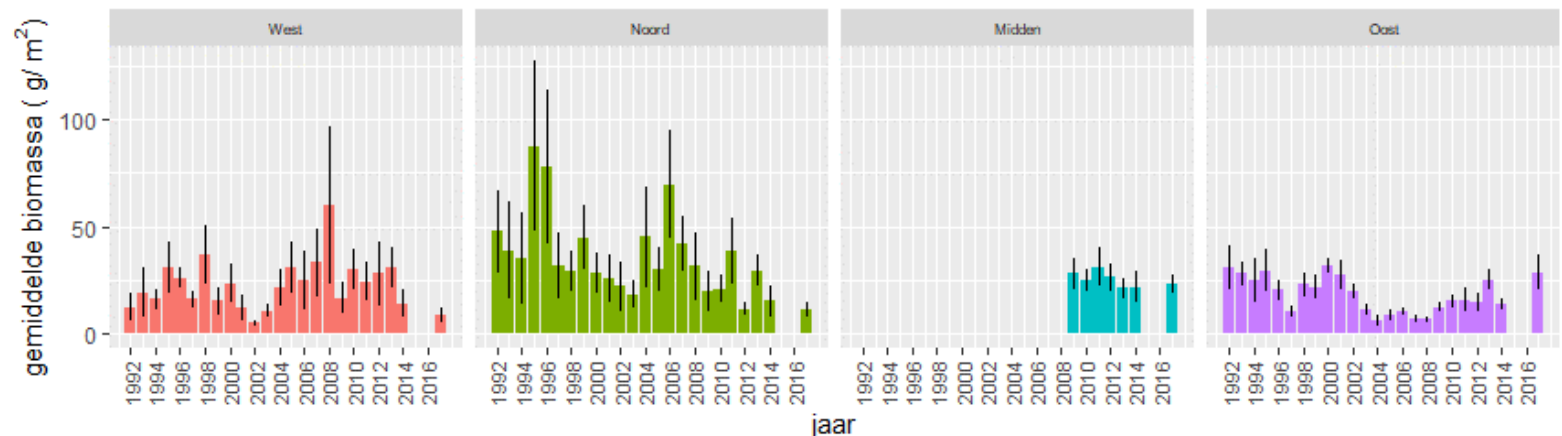

Figuur 7. Ruimtelijke verschillen en temporele veranderingen in de gemiddelde totale dichtheid en totale biomassa (asvrij drooggewicht) per monsterpunt in de vier onderscheiden deelgebieden in de Oosterschelde (gemiddelde en standaardfout) (data MWTL; 1992-2017 met uitzondering van 2015 en 2016, deelgebied Midden vanaf 2009) 

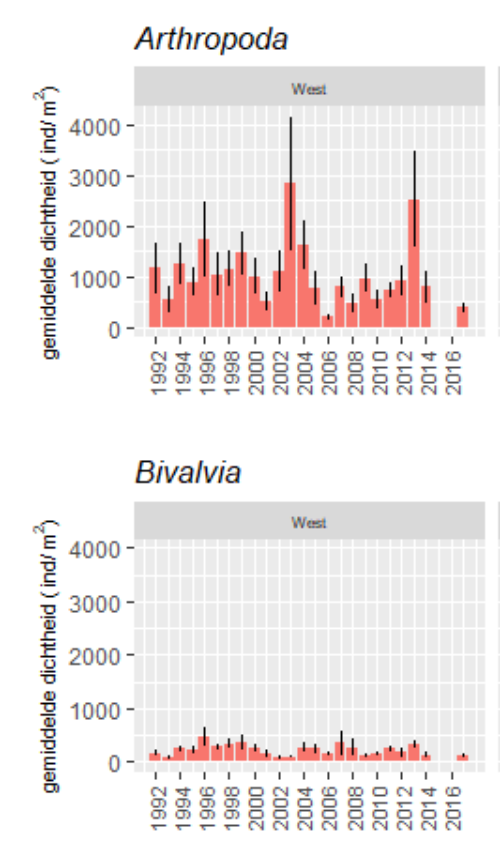

Gastropoda

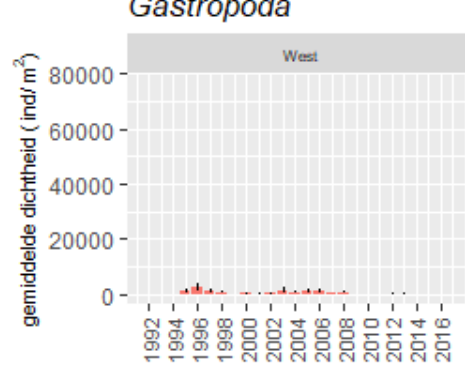

Annelida

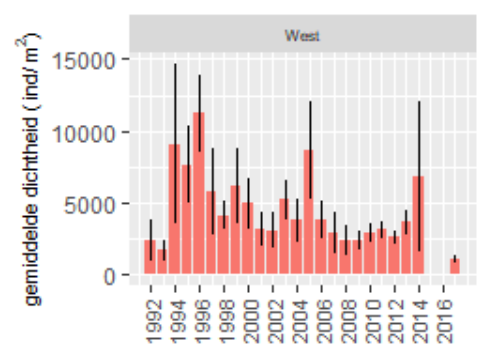

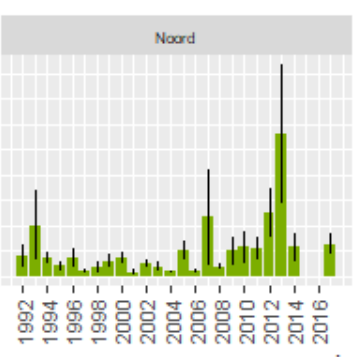

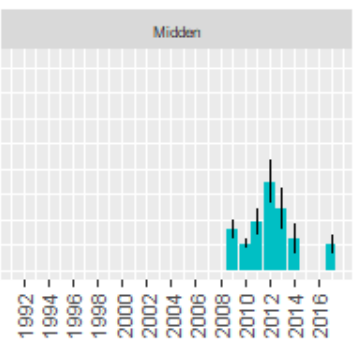
jaar
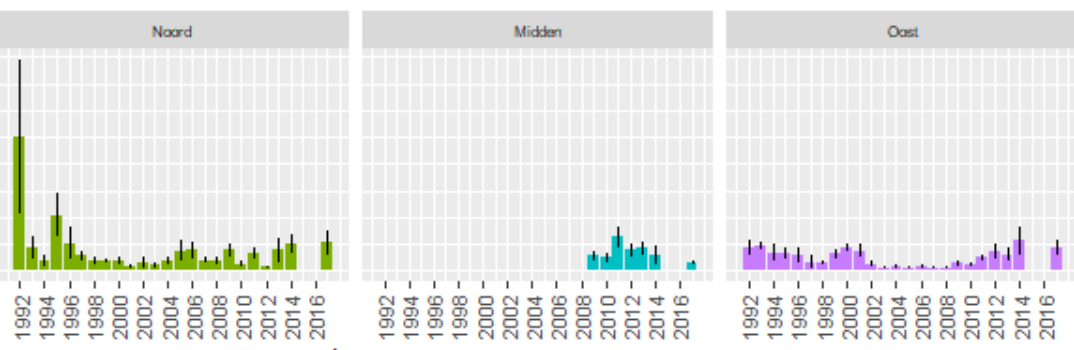

jaar
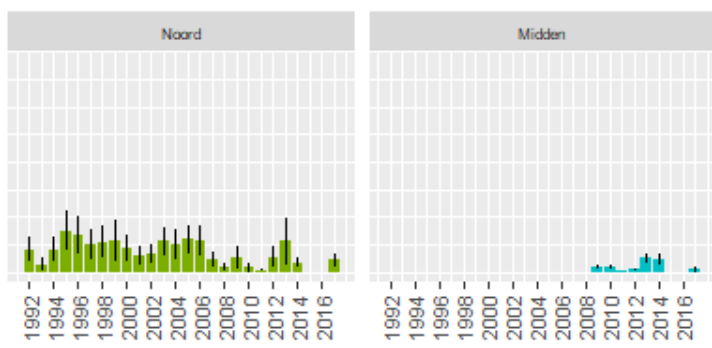

jaar

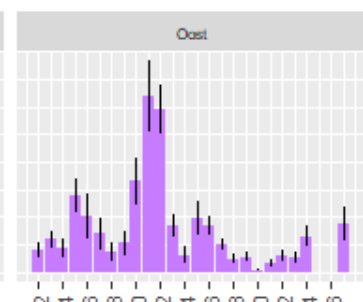

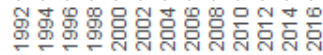
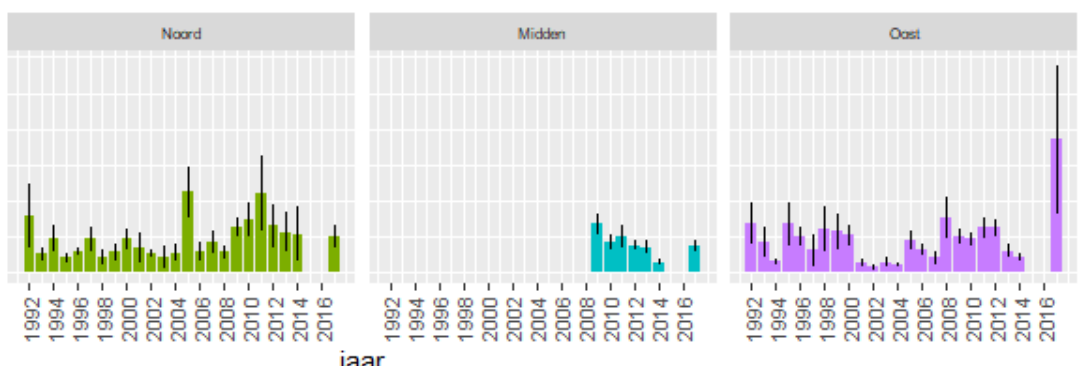

Figuur 8. Ruimtelijke verschillen en temporele veranderingen in de gemiddelde totale dichtheid per monsterpunt van kreeftachtigen (Arthropoda), tweekleppigen (Bivalvia), slakken (Gastropoda) en borstelwormen (Annelida) in de vier onderscheiden deelgebieden in de Oosterschelde (gemiddelde en standaardfout) (data MWTL; 1992-2017 met uitzondering van 2015 en 2016, deelgebied Midden vanaf 2009) 

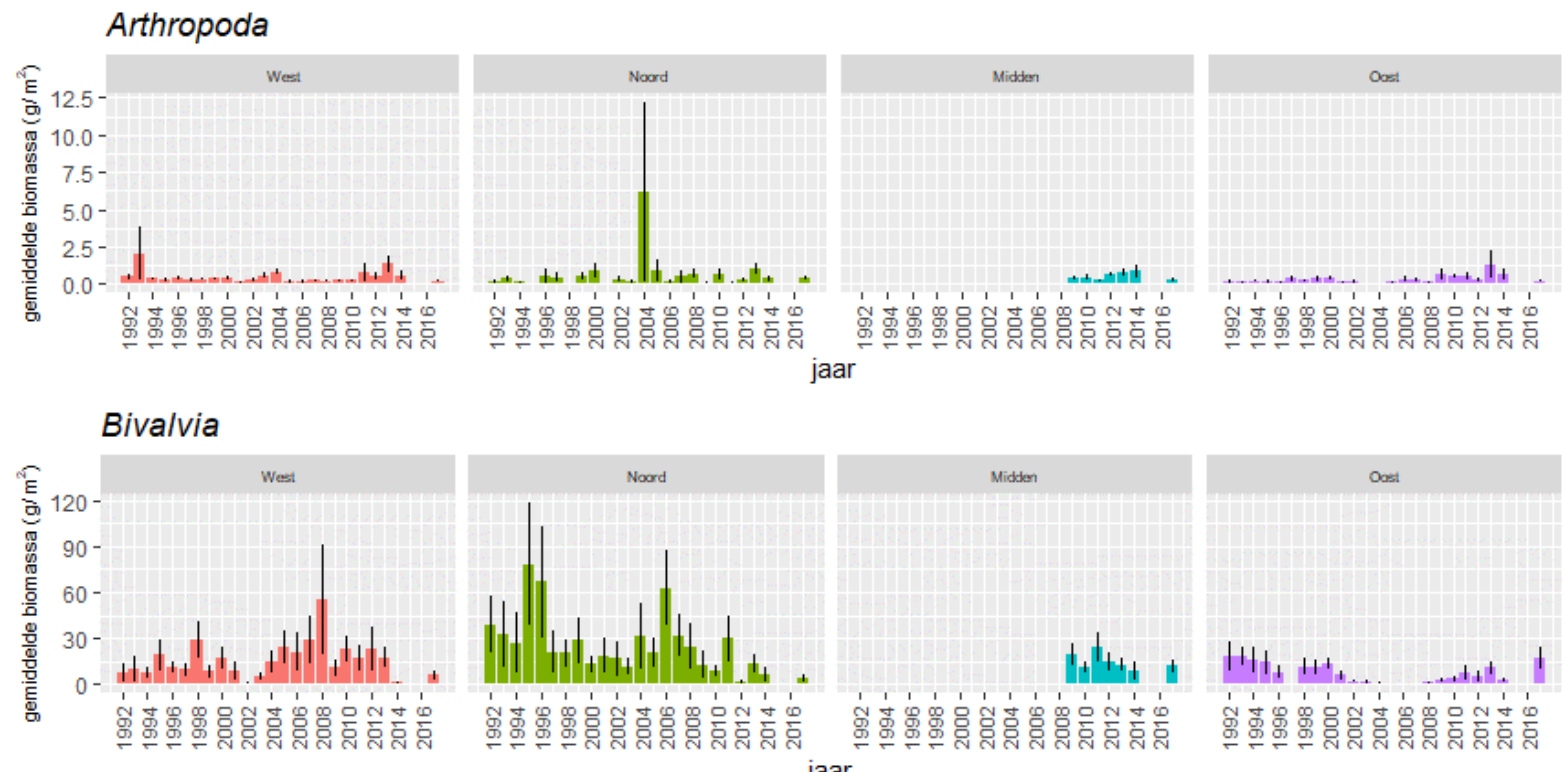

\section{Gastropoda}
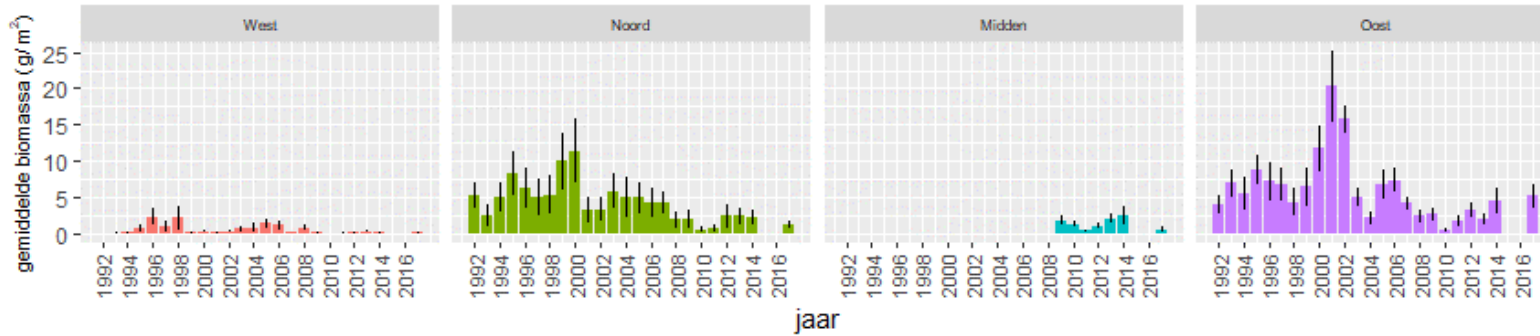
jaar

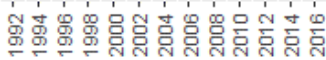

\section{Annelida}
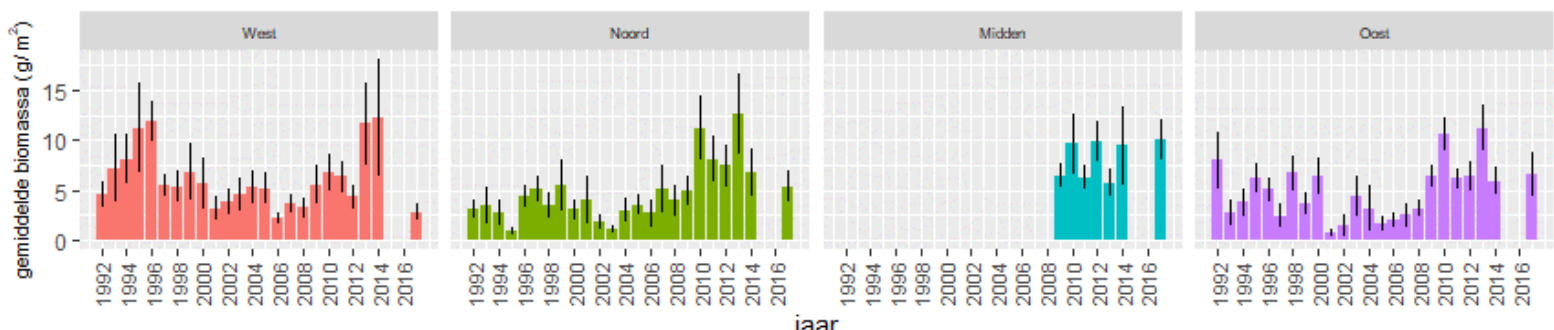

Figuur 9. Ruimtelijke verschillen en temporele veranderingen in de gemiddelde totale biomassa (asvrij drooggewicht) per monsterpunt van kreeftachtigen (Arthropoda), tweekleppigen (Bivalvia), slakken (Gastropoda) en borstelwormen (Annelida) in de vier onderscheiden deelgebieden in de Oosterschelde (gemiddelde en standaardfout) (data MWTL; 1992-2017 met uitzondering van 2015 en 2016, deelgebied Midden vanaf 2009) 


\subsubsection{Ruimtelijke verschillen en temporele veranderingen in biomassa van prooisoorten voor 12 soorten steltlopers}

De trends in gemiddelde totale biomassa van alle prooisoorten voor 12 soorten steltlopers (Figuur 10 t/m Figuur 12) volgt de trends van de klassen onderscheiden als prooisoorten (tweekleppigen, wormen, overige soorten), zeker als een soort vooral foerageert op een van deze groepen. Zoals bijv. de scholekster en de kanoet die vooral tweekleppigen eten, en de rosse grutto die vooral wormen eet (Tabel 1).

We zien dan ook een daling van het voedselaanbod voor de scholekster en de kanoet in Noord. Maar ook het voedselaanbod voor de steenloper daalt in dit deelgebied. In Oost lijkt de trend van prooien voor meerdere soorten (o.a. steenloper, groenpootruiter, zwarte ruiter, tureluur) voor een groot deel bepaald door de trend van wadslakjes. Het voedselaanbod was maximaal rond de eeuwwisseling. 

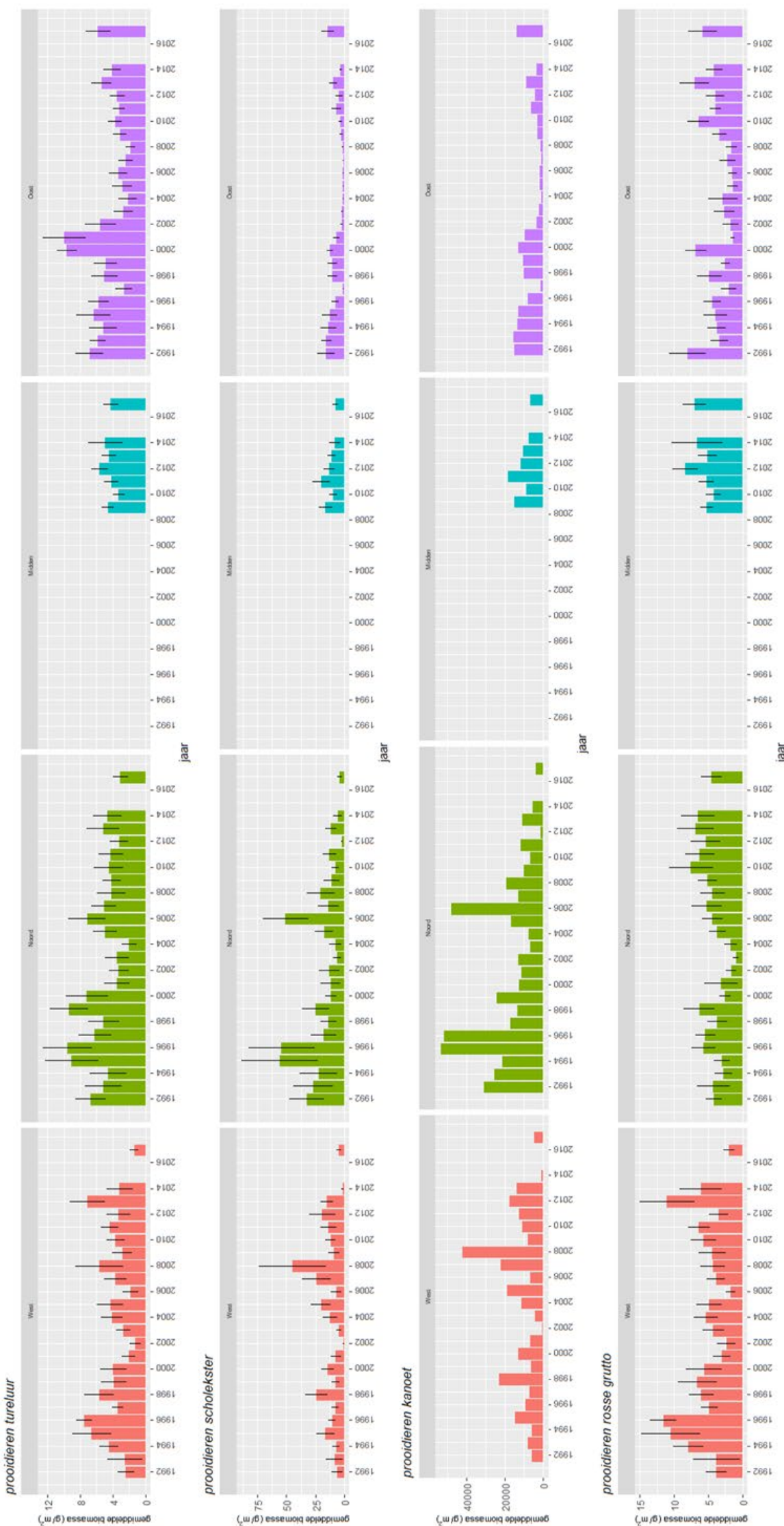

Figuur 10. Ruimtelijke verschillen en temporele veranderingen in de gemiddelde totale biomassa (asvrij drooggewicht) per monsterpunt van prooidieren voor tureluur, scholekster, kanoetstrandloper en rosse grutto (gemiddelde en standaardfout) (data MWTL; 1992-2017 met uitzondering van 2015 en 2016, deelgebied Midden vanaf 2009) 


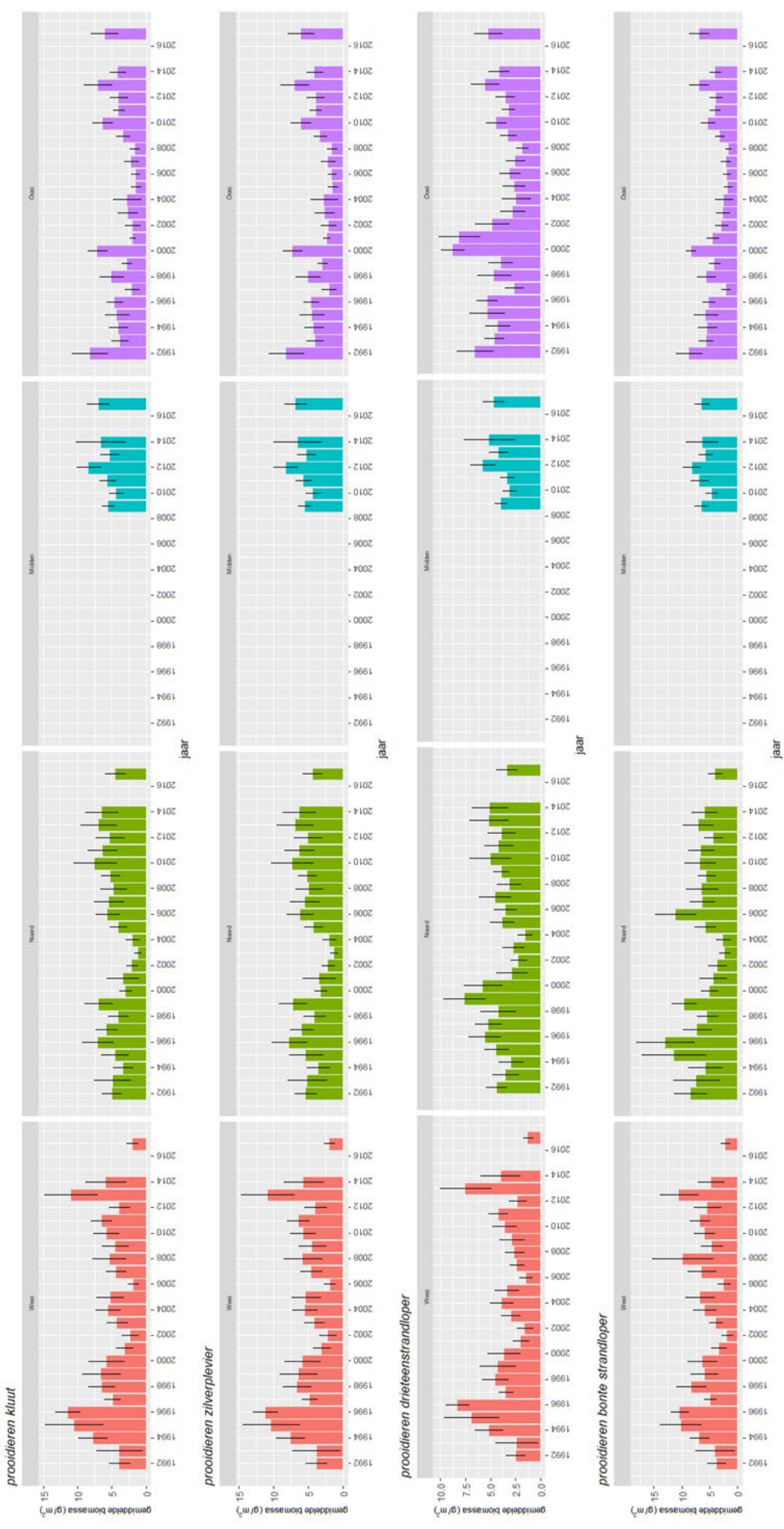

Figuur 11. Ruimtelijke verschillen en temporele veranderingen in de gemiddelde totale biomassa (asvrij drooggewicht) per monsterpunt van prooidieren voor kluut, zilverplevier, drieteenstrandloper en bonte strandloper (gemiddelde en standaardfout) (data MWTL; 1992-2017 met uitzondering van 2015 en 2016, deelgebied Midden vanaf 2009) 

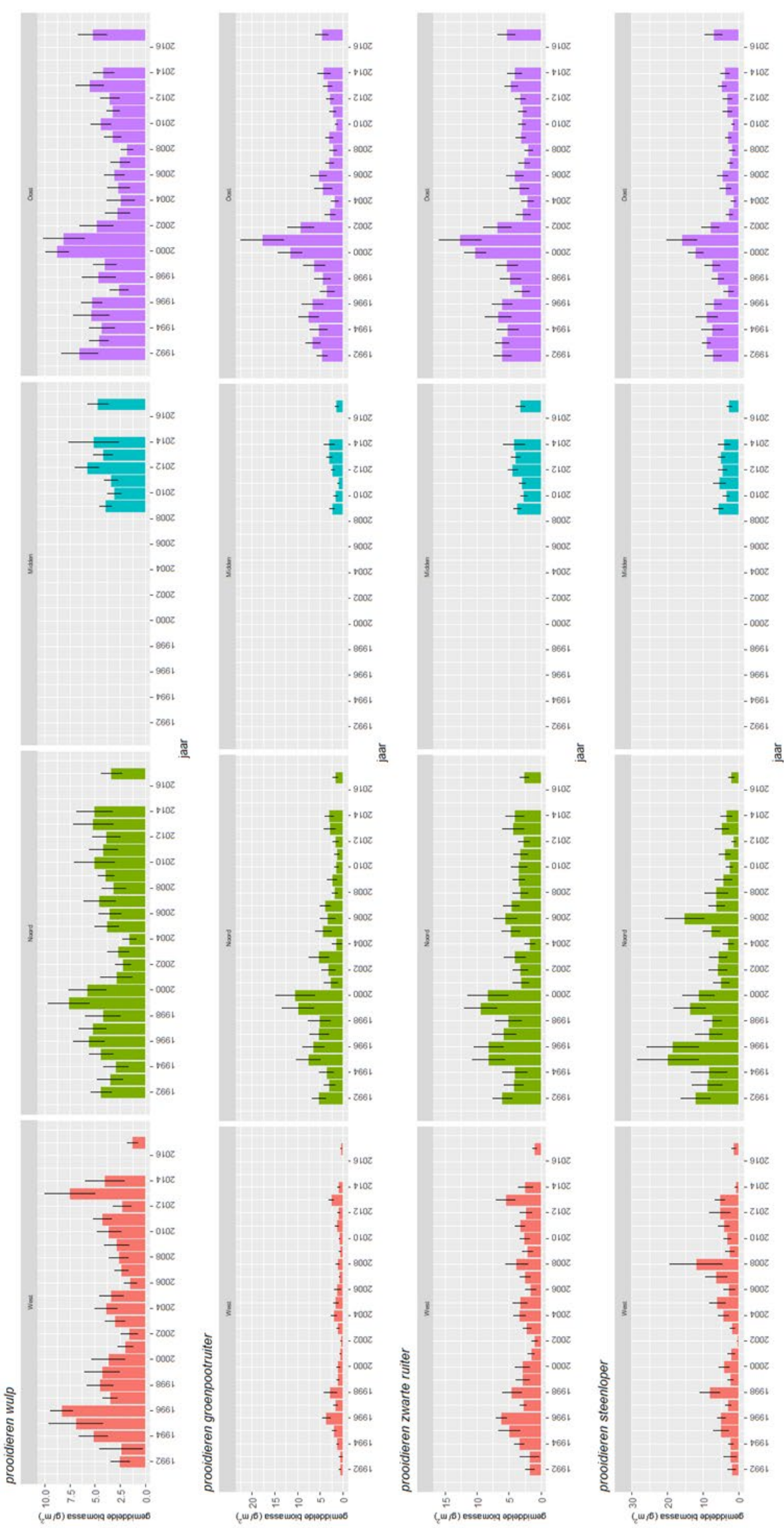

Figuur 12. Ruimtelijke verschillen en temporele veranderingen in de gemiddelde totale biomassa (asvrij drooggewicht) per monsterpunt van prooidieren voor wulp, groenpootruiter, zwarte ruiter en steenloper (gemiddelde en standaardfout) (data MWTL; 1992-2017 met uitzondering van 2015 en 2016, deelgebied Midden vanaf 2009) 


\subsubsection{Data WOT}

Het Wettelijk Onderzoek schelpdieren is uiteraard gericht op schelpdieren. In de Oosterschelde gaat het dan primair om de kokkel (C. edule) en het nonnetje (L. balthica).

Figuur 13 geeft de gemiddelde dichtheid van kokkels zoals berekend aan de hand van de WOT-data. Met name in Oost en West zien we periodes met veel lagere dichtheden. In West lijkt er een herstel ingezet na de afname in de periode voor 2017, zoals te zien in de MWTL-data. Dat is nog niet te zien in de biomassa (Figuur 14). Ook in Oost worden de laatste jaren weer meer kokkels gevonden dan in een lange periode daarvoor, en dat is ook vertaald in een toename in de biomassa. In Noord is met name de biomassa de laatste jaren (vanaf 2011) laag in vergelijking met de meeste jaren ervoor.

Het nonnetje heeft de hoogste dichtheden in West (Figuur 13). In alle deelgebieden is de dichtheid de laatste tien jaar veelal hoger dan in de voorgaande jaren. De biomassa volgt globaal dezelfde trend (Figuur 14).
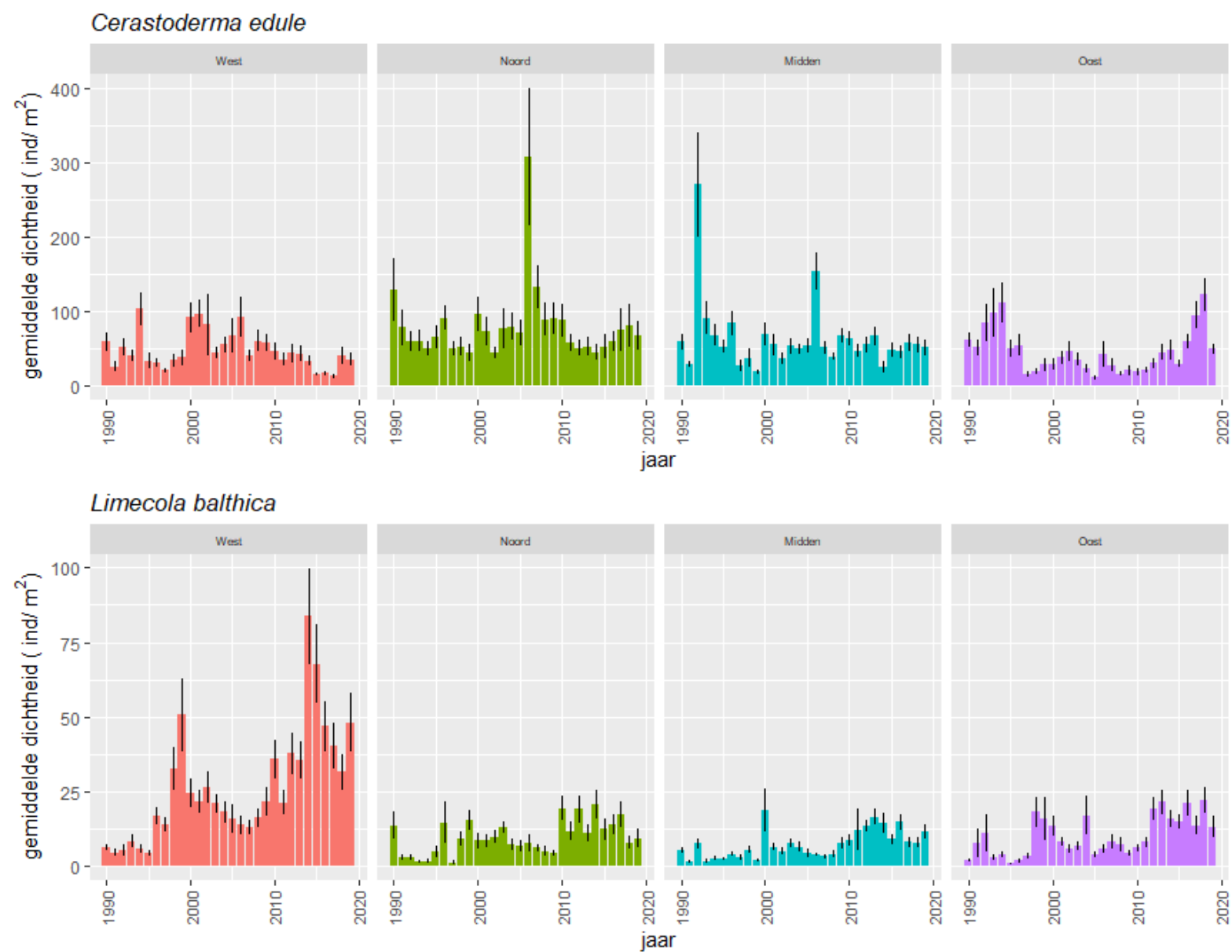

Figuur 13. Ruimtelijke verschillen en temporele veranderingen in de gemiddelde dichtheid per monsterpunt van kokkels (C. edule) en nonnetjes (L. balthica) (gemiddelde en standaardfout) (data WOT 1990-2019) 

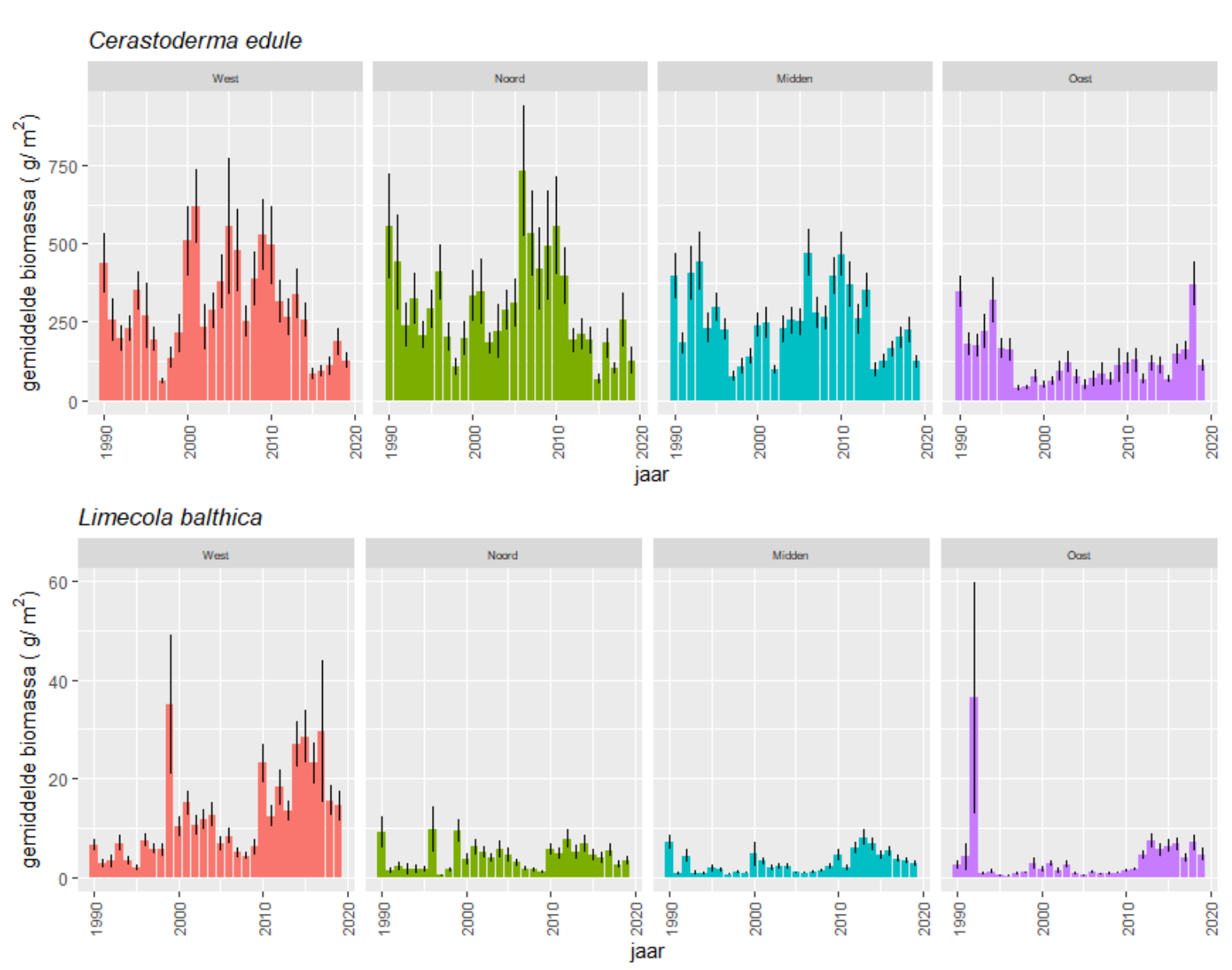

Figuur 14. Ruimtelijke verschillen en temporele veranderingen in de gemiddelde biomassa (versgewicht) per monsterpunt van kokkels (C. edule) en nonnetjes (L. balthica) (gemiddelde en standaardfout) (data WOT 1990-2019) 


\subsection{Droogvalduur}

Figuur 15 geeft de oppervlaktes per droogvalduurklasse voor de jaren 2001, 2010 en 2016, per deelgebied. Daarbij dient opgemerkt dat de waardes voor de laagste droogvalduurklassen in 2001 in de meeste gebieden overschat lijken, Laseraltimetrie stond toen nog in de kinderschoenen, en dit moet als een artefact gezien worden (mond. med. E. van Zanten). Ook de waardes bij droogvalduren vanaf $80 \%$ zijn niet betrouwbaar omdat het vooral om schorren gaat en de hoogte daarvan niet betrouwbaar te meten is met laseraltimetrie (mond. med. E. van Zanten).

Vanaf 2001 lijkt enkel in het deelgebied West nog een afname van het areaal met droogvalduren van 60 tot 85\%. De afname in deelgebied Oost, die Troost \& Ysebaert (2011) constateerden tussen met name 1990 en 2001 voor droogvalduren van 40 tot 60\%, heeft zich niet verder gezet.
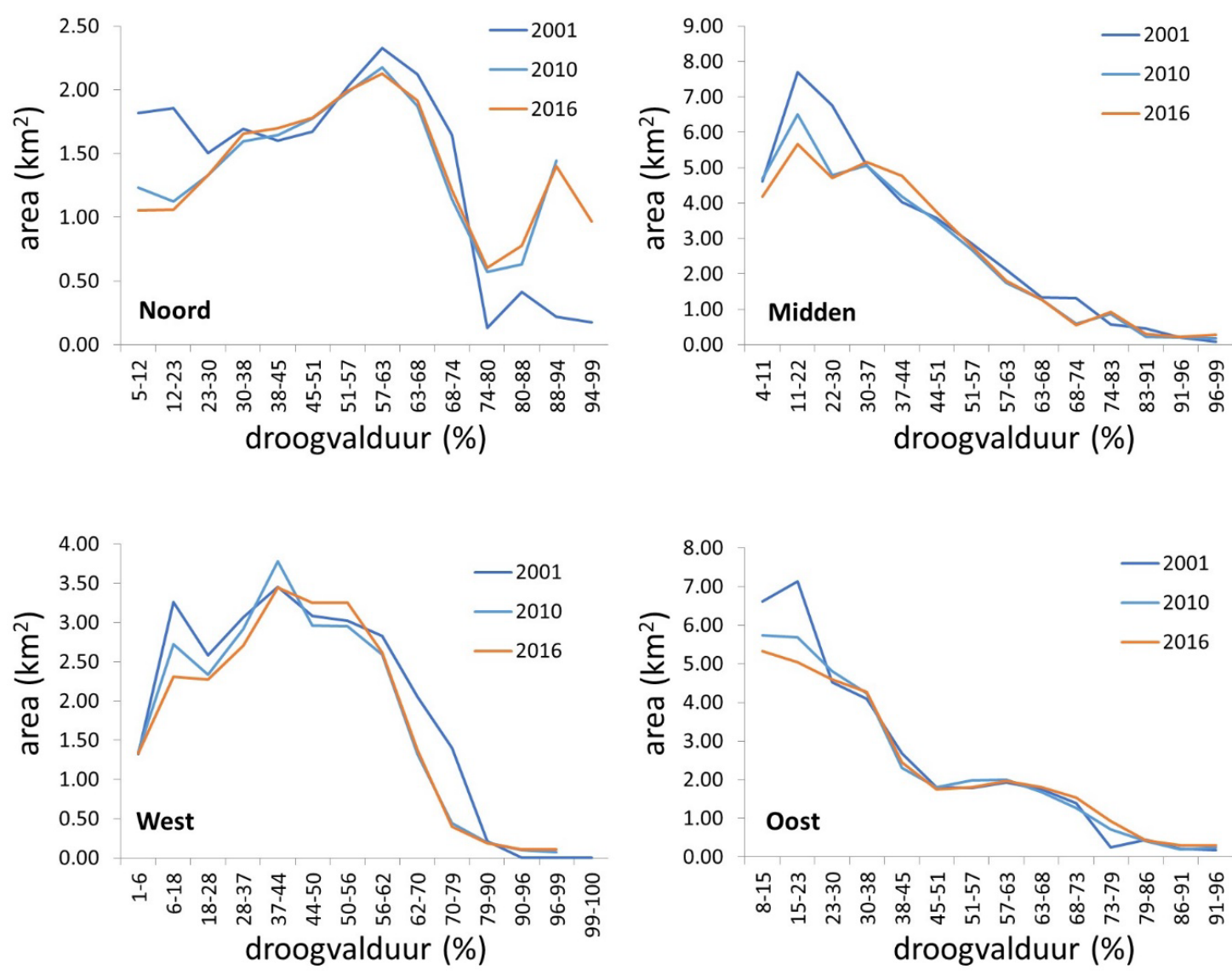

Figuur 15. Trends in de oppervlakte intergetijdengebied per droogvalduurklasse binnen ieder deelgebied van de Oosterschelde (jaren 2001, 2010 en 2016). Oppervlaktes berekend op basis van de droogvalduurkaarten (ref). Droogvalduurklassen als in Troost en Ysebaert (2011). 


\section{$4 \quad$ Discussie}

\subsection{Droogvalduur}

Sinds de bouw van de stormvloedkering in de monding van de Oosterschelde is het verschil tussen laagen hoogwater veel kleiner geworden wat al direct resulteerde in een afname van het intergetijdengebied met 700 ha (van Zanten and Adriaanse, 2008). Nadien is de periode van zandhonger ingetreden waarbij de slikken en platen kleiner werden en lager kwamen te liggen, met een gemiddelde snelheid van 0.7 $1 \mathrm{~cm}$ per jaar (de Vet et al., 2017; van Zanten and Adriaanse, 2008). Dat betekent dus een afname van de droogvalduur. In de periode 1986-2007 speelde dit vooral in het deelgebied Oost (de Kom), waarbij met name het gebied met droogvaltijden tussen 40 en 60\% afnam (Troost and Ysebaert 2011). De benthische biomassa, en voedselprooien voor steltlopers, is vooral hoog in gebieden met een droogvalduur kleiner dan 60\%. Kortom, de zandhonger kan niet alleen leiden tot een vermindering van het foerageergebied ( $6 \mathrm{~km}^{2}$ tussen 1990 en 2007, $15 \mathrm{~km}^{2}$ in 2019; Troost en Ysebaert 2011, Zandvoort et al 2019), maar ook op de aanwezige biomassa aan voedselprooien. Uit onze analyse blijkt er recent geen verdere verandering in arealen per droogvalduurklasse. Dit is in overeenstemming met de Vet et al. (2017) die concludeerde dat de erosiesnelheden de laatste jaren gereduceerd zijn.

\subsection{Datasets bodemdieren}

Over de jaren heen is het MWTL-programma aan veranderingen onderhevig geweest: verandering in bemonsteringsstrategie, verandering in bemonsterde oppervlakte, verandering in het analyseprotocol, verandering van uitvoerders. Dit kan een grote invloed hebben op de waargenomen bodemdierkarakteristieken en de trends daarin. Daarom wordt in vele richtlijnen aanbevolen om consistent eenzelfde bemonsteringsapparaat te gebruiken en eenzelfde bemonsteringsmethodiek te volgen. Zo niet, dan is het vaak enige voorzichtigheid nodig bij het interpreteren van de data (zie bijv. Rees et al., 2007). Zo neemt het aantal gevonden soorten toe met het aantal genomen monsters, en dus totaal bemonsterde oppervlakte (Heip et al., 1998). Ook elders in het Deltagebied, in het Grevelingenmeer, is vastgesteld dat het aantal gevonden taxa hoger was vanaf het moment dat de bemonsterde oppervlakte vergroot werd (Mulder et al., 2019). Dat is ook niet gek, want hoe groter het bemonsterde oppervlak hoe meer soorten men zal vinden. Verder worden er ook vaak andere interpretaties gegeven aan de identificatiesleutels bij analyses door verschillende laboratoria, resulterend in een iets andere soortensamenstelling. Dat vraagt extra aandacht om de soortensamenstelling 'gelijk' te trekken (zie bijv. Rees et al 2007). Bij geaggregeerde indices als dichtheden en biomassa's speelt dat geen rol. In de huidige analyses van dichtheden en biomassa's zien we ook geen in het oog springende trendbreuken.

In dit rapport zijn voor twee soorten, de kokkel en het nonnetje, trends gepresenteerd gebaseerd op twee datasets, MWTL en WOT. De monitoringprogramma's MWTL en WOT zijn in vele facetten verschillend: het seizoen waarin gemonsterd is, de bemonsteringsopzet, de gebruikte maaswijdte, ect. Het is dan ook logisch dat de trends (zeker deels) niet gelijk zijn. Zo kan een goede broedval in een bepaald jaar wel duidelijk zijn in de MWTL-data die in het najaar wordt uitgevoerd, maar na een strenge winter (hogere sterfte van schelpdieren) niet meer zichtbaar in de WOT-data die wordt uitgevoerd na de daarop volgende winter. Ruimtelijk zien we globaal wel dezelfde ruimtelijke patronen, bijv. een lagere biomassa van kokkels in het oostelijk deel, en de hoogste biomassa van het nonnetje in het westelijk deel. Ook uit habitatmodellen blijkt dat in de Oosterschelde gebieden als de Roggenplaat heel erg geschikt zijn, terwijl het oostelijk deel dit niet is (Kater et al., 2006). Uit deze studie blijken de hoogste biomassa voor te komen in gebieden met stroomsnelheden (bij eb tijdens springtij) tussen 27 en 37 $\mathrm{cm} / \mathrm{sec}$ en een droogvalduur van 42 tot $57 \%$. 
Voor sommige prooisoorten is de schatting en in MWTL en/of in WOT erg onnauwkeurig, gewoon omdat de bemonsteringsstrategie voor deze soorten niet optimaal is, zoals al aangegeven in Troost and Ysebaert (2011). De auteurs noemen een aantal endobenthische soorten, die in of op de bodem leven, en in relatief lage dichtheden voorkomen: Mya arenaria, Scrobicularia plana, Ensis leei, Crassostrea gigas, en Arenicola marina. Ook Mytilus edulis kan hieraan toegevoegd worden. Het gaat ook om epibenthische soorten, die op en vlak boven de bodem leven vaak mobiele soorten: Crangon crangon, Hemigrapsus sp. Carcinus maenas. Zeker een aantal van deze soorten zijn, tenminste tijdens een deel van het jaar, prooisoorten voor steltlopers (Zwarts, 2009; Zwarts et al., 2011).

\subsection{Trends in benthos}

Zowel de dichtheden als biomassa's kennen vaak grote temporele verschillen, zoals in eerdere studies in de Oosterschelde (bijv. Troost en Ysebaert 2011) en andere zoute wateren is vastgesteld. Dat geldt voor totale waardes, maar ook voor de waardes van hogere taxonomische niveaus (bijv. dichtheid aan borstelwormen in het westelijke deel) als van individuele soorten (bijv. dichtheid van het nonnetje). Belangrijke natuurlijke processen hieraan ten grondslag zijn het recruteringssucces en de mate van predatie, hydrodynamische omstandigheden (zoals windrichting in de periode van de larvale fase; zie bijv. Strasser et al., 2003) en meteorologische omstandigheden (denk aan water- en bodemtemperatuur; zie bijv. Armonies et al., 2001 en Suykerbuyk et al., 2020). Verder kunnen ook veranderingen in andere abiotische omstandigheden - zoals sedimentsamenstelling, saliniteit of droogvalduur - tot veranderingen leiden. Tot slot kunnen ook menselijke activiteiten kunnen deze veelal relatief niet of weinig mobiele soorten van invloed zijn, tijdelijk of permanent.

De totale biomassa in de noordelijke tak is in de loop der jaren zowat gehalveerd (Figuur 7). Dit komt door een lagere biomassa van schelpdieren (zowel tweekleppigen (kokkels) als slakken) terwijl de biomassa van borstelwormen er toegenomen is.

De biomassa in de kom (Oost) nam tot 2010 af (Troost and Ysebaert 2011) maar is nadien weer toegenomen. Dat komt deels - in sommige jaren - door opnieuw hogere biomassa's van de kokkel $C$. edule, te zien in zowel de MWTL- als de WOT-datareeks. Maar ook de biomassa aan borstelwormen is de laatste jaren meestal hoger dan bij het begin van de tijdsreeks, na een dip begin deze eeuw. Wat aan de grondslag ligt van deze toe- en afnames, hebben we in deze studie niet onderzocht. Troost and Ysebaert (2011) konden de veranderingen tot 2010 niet aan erosie van platen toeschrijven.

Ook ruimtelijk zijn er verschillen. De hoogste dichtheden zijn te vinden in de kom (Oost) van de Oosterschelde, de hoogste biomassa's in de noordelijke tak. De laagste dichtheden en biomassa zijn waargenomen in het westen. In het westen wordt de totale dichtheid gedomineerd door borstelwormen, in de noordelijke tak en het oosten door schelpdieren. De biomassa wordt overal door schelpdieren gedomineerd. Zoals al door Troost and Ysebaert (2011) gemeld is de schelpkokerworm L. conchilega (bijna) afwezig in het oostelijk deel, en heeft grote dichtheden (en biomassa's) in het westen.

\subsection{Steltopers en hun prooidieren}

Met name in de noordelijke tak zie je een daling van de biomassa aan prooien voor steltlopers die vooral schelpdieren eten, de scholekster en de kanoet. In dit deelgebied is er ook een afname van scholeksters in het laatste decennium (van Donk et al., 2020). Maar scholeksters nemen in de andere gebieden ook af, terwijl daar geen afname is aan schelpdieren. In het oosten was er een afname van de biomassa schelpdieren, met name kokkels, tot zo'n 10 jaar geleden, waarna er weer een toename was. De afname van scholeksters in deelgebied Oost is eerder toegeschreven aan een afname in de biomassa van prooidieren (Troost and Ysebaert 2011), en recent zien we daar weer een lichte toename van 
scholeksters (van Donk et al., 2020). Het aantalsverloop van kanoetstrandlopers is er een van toename tot begin deze eeuw, gevolgd door een afname (van Donk et al., 2020). Kortom, patronen in voedselaanbod, uitgedrukt per vierkante meter, spelen blijkbaar een belangrijke rol, maar niet voor alle soorten en niet in alle deelgebieden. Naast voedselaanbod zijn er dan ook allerlei andere factoren die het voorkomen van steltlopers beïnvloeden zoals de mate van verstoring en ontwikkelingen op flywayen (meta)populatieniveau.

Ook voor een aantal andere soorten lijkt de biomassa aan prooidieren in de noordelijke tak af te nemen, bijv. voor de steenloper en groenpootruiter. In de kom (Oost) neemt de biomassa aan prooisoorten de laatste jaren weer toe, na een afname begin deze eeuw. Toch lijken vooral in dit deelgebied de aantallen vogels zelf af te nemen (van Donk et al 2020). Dat zou erop kunnen wijzen dat een tekort aan voedsel niet de oorzaak is voor deze afnames. Andere factoren, zoals afnemend platenareaal, verstoring, veranderingen in meta-populatie, enz. spelen mogelijk een grotere rol.

Overigens vertonen de veranderingen in dichtheid en biomassa van de meeste prooidiersoorten, evenals van het totale aanbod aan prooidieren voor andere steltlopers, geen duidelijke trends.

Al bij al suggereren de korte-termijntrends van steltlopers in de Oosterschelde vergeleken met andere gebieden dat dat de foerageercondities in de Oosterschelde verslechteren (van Donk et al., 2020). Over de periode 2007-2017 is de achteruitgang van kanoetstrandloper, bonte strandloper, steenloper en groenpootruiter groter in de Oosterschelde dan elders. De kluut en bontbekplevier nemen toe in de flyway maar af in de Oosterschelde (Figuur 16). De achteruitgang van foerageercondities kan, zoals al aangegeven, zowel gaan over het aanwezige voedsel (bodemdieren) als over het plaatareaal.

Niet alle steltlopers eten alle en dezelfde soorten bodemdieren (Crielaard 1995, Leopold et al. 2004, Ens et al. 2005, Rappoldt \& Ens 2005, Zwarts et al. 2011, Bouwmeester 2014, Ens et al. 2015, Ens et al. 2016). Voor een vogelsoort blijken vaak verschillen in prooikeuzes te bestaan naar gelang het beschouwde gebied, en zelfs binnen een watersysteem, en afhankelijk van het seizoen (Zwarts et al 2011, Bouwmeester 2014). Tevens kunnen er verschillen voorkomen naargelang het geslacht, zoals vastgesteld bij de rosse grutto (Duijns, 2014; Zwarts et al., 2011)). In deze studie hebben we prooikeuzes vrij algemeen geselecteerd, op basis van overzicht in Leopold et al (2004), om in ieder geval grote verschillen in prooikeuze te kunnen duiden (bijv. wormen versus tweekleppigen als belangrijkste voedselbron). Maar wellicht is een gedetailleerdere inschatting nodig voor verdere koppeling tussen benthos en steltlopers, in ruimte en tijd. Voor scholeksters is wellicht de voedselconditie specifiek in het najaar verslechterd (van Donk et al 2020).

Hierop aansluitend is het belang van specifieke prooidieren voor een aantal steltlopers in deze studie wellicht onderschat. Zo noemen Troost en Ysebaert (2011) het wadslakje ( $P$. ulvae) als belangrijke voedselbron voor zilverplevieren. En ze vonden een significante relatie tussen de dichtheden van dit slakje en de seizoensgemiddelde aantallen zilverplevieren in het oostelijk deel van de Oosterschelde. In onze berekeningen van de dichtheid en biomassa aan prooidieren voor deze steltloper zijn we ervan uitgegaan dat ze $87 \%$ borstelwormen eten, naast tweekleppigen (6\%) en overige soorten (7\%), waaronder het wadslakje (Tabel $\mathbf{1}$ ). In het tijdsverloop van totale aanbod aan prooidieren zien we in het deelgebied Oost geen duidelijke trend, terwijl er sinds de eeuwwisseling wel sprake is van een toename van zilverplevieren, na een afname in de voorafgaande decennia (van Donk et al 2020). Anderzijds is er ook voor het wadslakje zelf geen duidelijke trend, en eerder sprake van toename in vorige eeuw met de hoogste aantallen (en biomassa) rond de eeuwwisseling, en afname deze eeuw (bijlage 1). Voor zilverplevieren is er de laatste decennia een toename, ondanks een afname van het wadslakje in deze periode. Beschikbaarheid van deze prooisoort heeft dus geen belangrijke rol gespeeld voor de populatie zilverplevieren. 


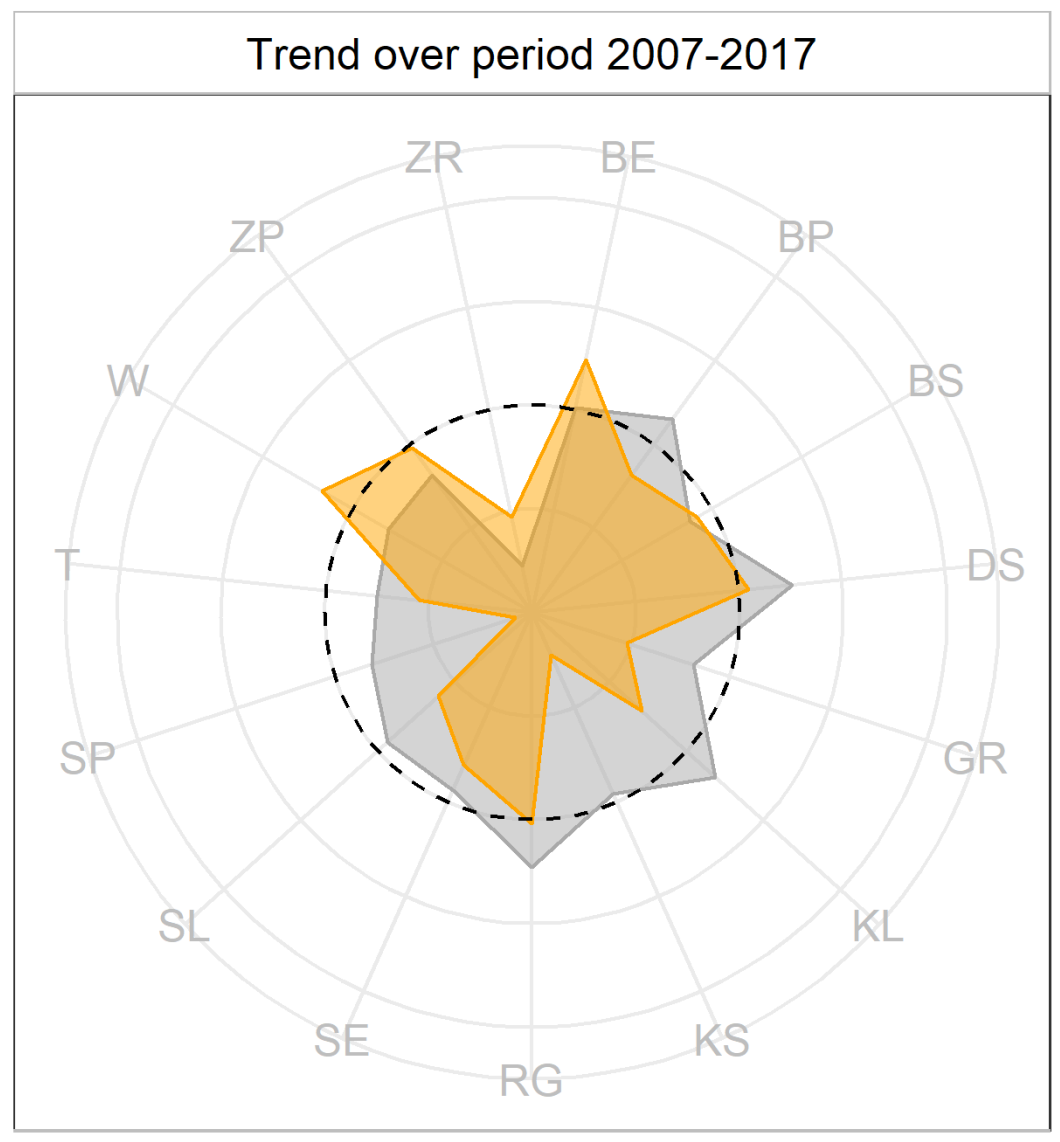

Flyway

Oosterschelde

Figuur 16. Amoebe-diagram van steltlopers en andere benthos etende vogels in de Oosterschelde. De cirkel vertegenwoordigt de situatie in 2007 (100\%). De procentuele verschillen in de Oosterschelde en flyway ten opzichte van de referentie zijn weergegeven in geel en grijs. (ZR zwarte ruiter, BE bergeend $B P$ bontbekplevier, BS bonte strandloper, DS drieteenstrandloper, GR groenpootruiter $K L$ kluut $K S$, $R G$ rosse grutto, SE scholekster, SL steenloper, SP strandplevier, $T$ tureluur, W wulp, ZP zilverplevier) (figuur S. van Donk)

In het verleden waren mosselen vooral aanwezig in de litorale kweekpercelen (Craeymeersch et al., 1986; Smaal and van Stralen, 1990), waarop door steltlopers gefoerageerd werd (Meire, 1993; Meire and Kuyken, 1984; Meire and Ervynck, 1986). Halverwege de jaren 90 zijn de litorale banken verplaatst naar het sublitoraal, en de daling van het aantal scholeksters is al eerder hieraan toegeschreven (Troost and Ysebaert 2011). Tegenwoordig komen mosselen in het litoraal met name voor op dijken en in de litorale oesterbanken, en daar foerageren zeker scholeksters op (mond. med. K. Troost).

Niet alleen de gemiddelde dichtheid en/of biomassa aan prooidieren in het litoraal is van belang, maar ook het totale aanbod en de ruimtelijke verdeling over de platen.

Het totale voedselaanbod wordt mede bepaald door het platenareaal. Troost and Ysebaert (2011) rapporteren dat de afname van prooidieren het grootst was in deelgebied Oost, en de komende decennia wordt ook daar de grootste afname verwacht (De Ronde et al., 2013). Daar zijn ook de grootste afname van vogelaantallen gesignaleerd (van Donk et al., 2020). 
Wellicht nog van groter belang is de verdeling over de getijzone. De benthische biomassa is het hoogst in gebieden met een droogvalduur van minder dan 60\% (Troost and Ysebaert 2011). Voor steltlopers is het gedeelte van de platen die $40 \%$ tot $60 \%$ van de tijd droogvallen, het belangrijkst als foerageergebied (van Donk et al 2020). Deze droogvalduurklasse neemt het snelst af in deelgebied West (De Ronde et al. 2013). Het totaal aantal vogels neemt nog niet af in dit gebied (van Donk et al 2020). Een aantal vogelsoorten nemen in dit gebied af in aantal, andere juist toe. Anderzijds komen de prooisoorten ook niet allemaal met de hoogste biomassa voor bij dezelfde droogvalduur, en kun je dan ook verwachten dat bepaalde steltlopers in het hoge litoraal (droogvalduur $>40 \%$ ) of juist in het lagere litoraal (droogvalduur < 40\%) zullen foerageren (Troost and Ysebaert 2011). Van Donk et al (2020) concluderen dat de patronen van platenareaal en vogelaantallen en soorten niet eenduidig zijn, en dat er nadere analyses moeten komen met recentere metingen aan beschikbaar platenareaal in het veld in relatie tot vogelaantallen.

Vraag is ook of onder de huidige omstandigheden de relatie tussen bodemdiergroepen of -soorten en droogvalduur dezelfde gebleven zijn. En of veranderingen in het benthos toegeschreven kunnen worden aan veranderingen in droogvalduur. Dat vraagt om nadere analyse van de dieptekaarten. Voor zover ons bekend, is de laatste dieptekaart die omgezet is in een droogvalduurkaart deze van 2009. Overigens speelt voor de bodemdieren zelf niet alleen de droogvalduur een rol. Naast de lengte van de overspoelingsperiode speelt ook de overspoelingsfrequentie een rol, de momenten in het jaar van hogere en lagere overspoelingsperiodes en -frequenties, en de waterhoogte bij vloed. Deze bepalen mede de aanvoer van larven en verspreiding ervan over de platen (Craeymeersch, 1999a; Craeymeersch et al., 1988; Wolff, 1973).

Al bij al lijkt de volgende stap dus mogelijk: een analyse van vogeltrends gerelateerd aan de beschikbare prooidieren en veranderingen in platenareaal en droogvalduur. Om zo beter inzicht te krijgen over de oorzaak van de verslechterde vogeltrends. Vraag is wel of de ruimtelijke schaal - de vier deelgebieden - niet te groot is. Wellicht dat binnen een deelgebied een bepaalde plaat beter of slechter wordt. En dan zijn voor een goede analyse van de relaties meer details nodig over zowel de ruimtelijke verschillen in het benthos als over het gebruik door steltlopers bij laagwater. 


\section{Conclusies en aanbevelingen}

Concluderend kunnen we stellen dat ondanks de veranderingen in de MWTL-bemonsteringsstrategie deze samen met de WOT-data (voor bepaalde soorten) een goed beeld geven over de globale, trends van de dichtheid en biomassa van belangrijke prooidieren voor steltlopers in de verschillende deelgebieden van de Oosterschelde.

We constateren daarbij een daling van het voedselaanbod voor de scholekster en de kanoet, met name schelpdieren, in de noordelijke tak (Noord). Maar ook het voedselaanbod voor de steenloper daalt in dit deelgebied, voor een groot deel te wijten aan de afname van wadslakjes. Ook in de Kom (Oost) lijkt de trend van prooien voor meerdere soorten (o.a. steenloper, groenpootruiter, zwarte ruiter, tureluur) voor een groot deel bepaald door de trend van wadslakjes. Het voedselaanbod was daar maximaal rond de eeuwwisseling.

Maar niet alleen de gemiddelde dichtheid en biomassa aan prooidieren bepaalt of een gebied geschikt en/of gebruikt wordt door steltlopers. Ook het totale aanbod, mede bepaald door het platenareaal, en de verdeling over de bij eb droogvallende gebieden (droogvalduur) zijn van belang. Deze laatste heeft zowel invloed op de bodemdieren zelf, als op de beschikbare tijd voor steltlopers om in de delen met de hoogste benthische biomassa te foerageren. Een goede analyse van de relatie tussen trends van steltlopers en bodemdieren, vereist daarom ook voldoende data over veranderingen in de droogvalduur.

De vraag is ook of de beschikbare informatie over de aantallen steltlopers en de bodemdieren wel voldoende is om oorzaken van veranderingen in aantallen steltlopers te kunnen inschatten, en of er een verband is met de zandhonger, direct (via veranderingen in plaatareaal en droogvalduur) of indirect (via veranderingen in het benthos). Uit onze analyse blijkt er sinds begin deze eeuw geen verdere verandering in arealen per droogvalduurklasse. Dat lijkt dus, in deze periode, geen rol gespeeld te hebben m.b.t. de trends in aantallen steltlopers. De vogels worden binnen het MWTL-programma geteld op hoogwatervluchtplaatsen, en geven dus geen informatie over het gebruik van droogvallende platen en slikken. Ook de informatie over de veranderingen in het benthos binnen deelgebieden is op basis van het MWTL-programma naar verwachting beperkt, omdat het aantal monsters op die plekken waar steltlopers foerageren waarschijnlijk zeer klein is Enkel laagwatervogeltellingen kunnen een beeld geven over waar steltlopers foerageren en - gecombineerd met gedetailleerde informatie over bodemdieren en abiotische omstandigheden waaronder droogvalduur - waarom ze op bepaalde plaatsen voorkomen (los van verstoringen). Kortom, dit vereist een specifiek programma zoals momenteel in de Westerschelde uitgevoerd wordt (zie o.a. Boudewijn et al., 2019; Craeymeersch and Ysebaert, 2000). Een meer gedetailleerde studie van morfologische ontwikkelingen, bodemdieren (voedselaanbod en kwaliteit) en gebruik door steltlopers wordt momenteel wel uitgevoerd op de Roggenplaat (Ysebaert et al., 2016b). Het onderzoek loopt in een eerste fase tot 2025. Het doel van de monitoring is om na te gaan of middels een suppletie de huidige foerageerfunctie voor de komende 25 jaar behouden kan blijven. Wellicht kunnen de komende resultaten een beter, globaal, beeld geven of de uit MWTL en WOT beschikbare informatie over bodemdieren en steltlopers voldoende is en, zo niet, welke aanvullende informatie nodig is om te kunnen inschatten of veranderingen in aantallen steltlopers al of niet verband houden met de zandhonger. 


\section{$6 \quad$ Kwaliteitsborging}

Wageningen Marine Research beschikt over een ISO 9001:2015 gecertificeerd kwaliteitsmanagementsysteem. Dit certificaat is geldig tot 15 december 2021. De organisatie is gecertificeerd sinds 27 februari 2001. De certificering is uitgevoerd door DNV GL.

Het chemisch laboratorium te IJmuiden beschikt over een EN-ISO/IEC 17025:2017 accreditatie voor testlaboratoria met nummer L097. Deze accreditatie is geldig tot 1 april 2021 en is voor het eerst verleend op 27 maart 1997; deze accreditatie is verleend door de Raad voor Accreditatie. Het chemisch laboratorium heeft hierdoor aangetoond in staat te zijn op technisch bekwame wijze valide resultaten te leveren en te werken volgens de IS017025 norm. De scope (L097) met de geaccrediteerde analysemethoden is te vinden op de website van de Raad voor Accreditatie (www.rva.nl).

Op grond van deze accreditatie is het kwaliteitskenmerk $\mathrm{Q}$ toegekend aan de resultaten van die componenten die op de scope staan vermeld, mits aan alle kwaliteitseisen is voldaan. Het kwaliteitskenmerk $\mathrm{Q}$ staat vermeld in de tabellen met de onderzoeksresultaten. Indien het kwaliteitskenmerk $Q$ niet staat vermeld is de reden hiervan vermeld.

De kwaliteit van de analysemethoden wordt op verschillende manieren gewaarborgd. De juistheid van de analysemethoden wordt regelmatig getoetst door deelname aan ringonderzoeken waaronder die georganiseerd door QUASIMEME. Indien geen ringonderzoek voorhanden is, wordt een tweede lijnscontrole uitgevoerd. Tevens wordt bij iedere meetserie een eerstelijnscontrole uitgevoerd.

Naast de lijnscontroles wordende volgende algemene kwaliteitscontroles uitgevoerd:

- Blanco onderzoek.

- Terugvinding (recovery).

- Interne standaard voor borging opwerkmethode.

- Injectie standard.

- Gevoeligheid.

Bovenstaande controles staan beschreven in Wageningen Marine Research werkvoorschrift ISW 2.10.2.105.

Indien gewenst kunnen gegevens met betrekking tot de prestatiekenmerken van de analysemethoden bij het chemisch laboratorium worden opgevraagd.

Indien sprake is van onbeheerste kwaliteit worden passende maatregelen genomen. 


\section{Literatuur}

Armonies, W., Herre, E., Sturm, M., 2001. Effects of the severe winter 1995/96 on the benthic macrofauna of the Wadden Sea and the coastal North Sea near the island of Sylt. Helgoland Mar Res 55, 170-175. Boudewijn, T.J., Zwerver, J., Sluijter, M., Hoekstein, M., Wolf, P., Lilipaly, S., van Straalen, K., Arts, F., Beuker, D., 2019. Vogeltellingen met afgaand water in de Westerschelde. Voortgangsrapportage september 2018 - augustus 2019. Bureau Waardenburg Rapportnr.19-208. Bureau Waardenburg, Culemborg.

Craeymeersch, J., 1999a. Chapter 7. Distinction between man-induced and natural changes in macrobenthic communities: application of the Analysis of Concentration. In: Craeymeersch, JA 1999. The use of macrobenthic communities in the evaluation of environmental change. PhD Thesis, University of Gent. $p$. 195-219.

Craeymeersch, J., Ysebaert, T., 2000. Foerageergebieden voor steltlopers in de Westerschelde.

Voedselbeschikbaarheid en advies over bodemdierenbemonstering t.b.v. het aagwatervogeltelprogramma. Wageningen Marine Research rapport C108/19. .

Craeymeersch, J.A., 1999b. The use of macrobenthic communities in the evaluation of environmental change. PhD Thesis, University of Gent. $254 \mathrm{pp}$.

Craeymeersch, J.A., Coosen, J., van den Dool, A., 1988. Trendanalyse van densiteit- en biomassawaarden van bodemdieren in het getijdengebied van de Oosterschelde (1983-1986).

Craeymeersch, J.A., Herman, P.M.J., Meire, P.M., 1986. Secondary Production of an Intertidal Mussel (Mytilus-Edulis-L) Population in the Eastern Scheldt (Sw Netherlands). Hydrobiologia 133, 107-115. Craeymeersch, J.A., Ysebaert, T., Craeymeersch, J.A., Ysebaert, T., 2020. Foerageergebieden voor steltlopers in de Westerschelde : voedselbeschikbaarheid en advies over bodemdierenbemonstering t.b.v. het laagwatervogeltelprogramma. Wageningen Marine Research, Yerseke.

de Ronde, J., J.P.M. Mulder, J., L.A. van Duren, L., T. Ysebaert, T., 2013. Eindadvies ANT Oosterschelde. Deltares, $78 \mathrm{pp}$.

de Vet, P.L.M., van Prooijen, B.C., Wang, Z.B., 2017. The differences in morphological development between the intertidal flats of the Eastern and Western Scheldt. Geomorphology 281, 31-42.

Duijns, S., 2014. Sex-specific foraging. The distributional ecology of a polychaete-eating shorebird. PhD Thesis, University of Groningen, Groningen, The Netherlands.

Duijts, O., van der Jagt, H., van Moorsel, G., Kruijt, D., Japink, M., Middelveld, R., 2018.

Macrozoöbenthosbemonstering in de zoute Rijkswateren, Hoofdrapport 2017. Waterlichamen: Westerschelde en Oosterschelde. Bureau Waardenburg bv. Rapportnummer: 18-299. .

Duin, R.N.M., 1994. Poweranalyse bodemdieren Groninger Wad. Rijkswaterstaat, Rijksinstituut voor Kust en Zee. Werkdocument RIKZ/OS-94.121.

Escaravage, V., Hummel, H., Blok, D., Dekker, A., Engelberts, A., den Exter, T., Hartog, E., van Hoesel, O., Kleine Schaars L, Markusse, R., Meliefste, T., Sistermans, W., Wijnhoven, S., 2010.

MACROZOÖBENTHOSONDERZOEK MWTL IN DE DELTA, 2009. Waterlichamen: Grevelingenmeer en Veerse Meer (voor en najaar), Oosterschelde en Westerschelde (najaar). Rapportage in het kader van Monitoring Waterstaatkundige Toestand des Lands (MWTL). Monitor Taakgroep (KNAW/NIOO-CEME) Monitor Taskforce Publication Series 2010 - 05. 81 pp.

Escaravage, V., Hummel, H., Blok, D., Dekker, A., Engelberts, A., den Exter, T., Hartog, E., van Hoesel, O., Kleine Schaars L, Markusse, R., Meliefste, T., Sistermans, W., Wijnhoven, S., 2011.

MACROZOÖBENTHOSONDERZOEK MWTL IN DE DELTA, 2010. Waterlichamen: Grevelingenmeer en Veerse Meer (voor en najaar), Oosterschelde en Westerschelde (najaar). Rapportage in het kader van Monitoring Waterstaatkundige Toestand des Lands (MWTL). Monitor Taakgroep (KNAW/NIOO-CEME) Monitor Taskforce Publication Series 2011 - 09. 114 pp.

Heip, C., Herman, P., Soetaert, K., 1998. Indices of diversity and evenness*. Océanis 24, 61-87. Jacobse, J., van der Zel, M., Arnold, E., Hofstad, E., 2008. Toekomstprognose ontwikkeling intergetijdengebied Oosterschelde. Doorvertaling naar effecten op veiligheid en natuurwaarden. Royal Haskoning, Rotterdam. , .

Kater, B.J., Geurts van Kessel, A.J.M., Baars, J.J.M.D., 2006. Distribution of cockles Cerastoderma edule in the Eastern Scheldt: habitat mapping with abiotic variables. Mar Ecol Prog Ser 318, 221-227.

Kers, A.S., Walburg, L., Bakker, J., Daane, A., de Jong, D., Schrijver, M., Lievense, P., Dekker, L., de Klerk, J., 2013. Dienstbeschrijving Zoute ecotopenkarteringen. Rijkswaterstaat CIV/ZD, Delft / Middelburg. Leewis, L., Verduin, E.C., Wanink, J., 2015. Macrozoöbenthosonderzoek in de zoute Rijkswateren, Jaarrapportage MWTL 2013. Waterlichamen: Delta (Oosterschelde, Westerschelde, Greve-lingenmeer, Veerse Meer). Eurofins Omegam B.V., Eurofins AquaSense. 131 p. 
Leopold, M., Smit, C.J., Goedhart, P., van Roomen, M., van Winden, A., van Turnhout, C., 2004. Langjarige trends in aantallen wadvogels, in relatie tot de kokkelvisserij en het gevoerde beleid in deze. Eindverslag EVA II (Evaluatie Schelpdiervisserij tweede fase). Deelproject C2. Alterra, Wageningen. Alterra-rapport 954. Meire, P., 1993. Wader populations and macrozoobenthos in a changing estuary: the Oosterschelde (The Netherlands). Thesis University of Gent, p. 311.

Meire, P., Kuyken, E., 1984. Relations between the distribution of waders and the intertidal benthic fauna of the Oosterschelde, Netherlands, in: Evans, P.R., Goss-Custard, J.D., Hale, W.G. (Eds.), Coastal waders and wildfowl in winter. Cambridge University Press, Cambridge-NY-New Rochelle-Melbourne-Sydney, pp. 57-68. Meire, P.M., Ervynck, A., 1986. Are Oystercatchers (Haematopus-Ostralegus) Selecting the Most Profitable Mussels (Mytilus-Edulis). Anim Behav 34, 1427-1435.

Mulder, I., Escaravage, V., Tangelder, M., Ysebaert, T., 2019. Ontwikkelingen van het macrozoöbenthos in het Grevelingenmeer 1992-2016. Wageningen Marine Research, Yerseke.

Rees, H.L., Eggleton, J.D., Rachor, E., Vanden Berghe, E., 2007. Structure and dynamics of the North Sea benthos. ICES Cooperative Research Report No. 288. 258 pp., p. 258.

Sistermans, W., Hummel, H., Bergmeijer, M., Blok, D., Engelberts, A., de Witte-Dek, L., Dekker, A., van Hoesel, O., Kleine Schaars, L., Markusse, M., 2009. HET MACROBENTHOS VAN DE WESTERSCHELDE, DE OOSTERSCHELDE, HET VEERSE MEER EN HET GREVELINGENMEER IN HET VOOR- EN NAJAAR VAN 2008. Rapportage in het kader van het Biologisch Monitoring Programma. Nederlands Instituut voor Ecologie, Centrum voor Estuariene en Mariene Ecologie., Yerseke. 108 pp.

Smaal, A.C., van Stralen, M.R., 1990. Average Annual Growth and Condition of Mussels as a Function of Food Source. Hydrobiologia 195, 179-188.

Strasser, M., Dekker, R., Essink, K., Gunther, C.P., Jaklin, S., Kroncke, I., Madsen, P.B., Michaelis, H., Vedel, G., 2003. How predictable is high bivalve recruitment in the Wadden Sea after a severe winter? J Sea Res 49, 47-57.

Suykerbuyk, W., Tangelder, M., Walles, B., Suykerbuyk, W., Tangelder, M., Walles, B., 2020. Hittestress op de intergetijdenplaten van de Oosterschelde : temperatuurmetingen in de bodem van droogvallende platen in de zomer van 2019. Wageningen Marine Research, Den Helder.

Thrush, S.F., Hewitt, J.E., Cummings, V., Ellis, J.I., Hatton, C., Lohrer, A., Norkko, A., 2004. Muddy waters: elevating sediment input to coastal and estuarine habitats. Front Ecol Environ 2, 299-306.

Troost, K., Ysebaert, T., 2011. ANT Oosterschelde: long-term trends of waders and their dependence on intertidal foraging grounds. IMARES Wageningen UR, IJmuiden.

Troost, K., Ysebaert , T., 2011. ANT Oosterschelde: Long-term trends of waders and their dependence on intertidal foraging grounds. IMARES Wageningen UR. Report number C063/11. 93 pp.

van Asch, M., van den Ende, D., van der Pool, J., Brummelhuis, E., van Zweeden, C., van Es, Y., Troost, k., 2019. Het kokkelbestand in de Nederlandse kustwateren in 2019. Stichting Wageningen Research, Centrum voor Visserijonderzoek (CVO). CVO rapport: 19.009. 28 pp.

van der Meer, J., 1997. Sampling design of monitoring programmes for marine benthos: a comparison between the use of fixed versus randomly selected stations. J Sea Res 37, 167-179.

van Donk, S., Ysebaert , T., Tulp, I., 2020. Trends van steltlopers en andere benthos etende vogels in de Oosterschelde: 1987 - 2017/2018 . Wageningen Marine Research rapport C120/20. .

van Zanten, E., Adriaanse, L.A., 2008. Verminderd getij. Verkenning naar mogelijke maatregelen om het verlies van platen, slikken en schorren in de Oosterschelde te beperken. Rijkswaterstaat, $80 \mathrm{pp}$.

Verduin, E.C., Boonstra, H., Leewis, L., 2015. Macrozoöbenthosonderzoek in de zoute Rijkswateren, Jaarrapportage MWTL 2014. Waterlichamen: Delta (Oosterschelde, Westerschelde). Eurofins Omegam B.V., Eurofins AquaSense. $81 \mathrm{p}$.

Verduin, E.C., Leewis, L., van Haaren, T., 2018. Macrozoöbenthosonderzoek in de zoute Rijkswateren 2016, Delta. (Grevelingen, Oosterschelde, Westerschelde en Veerse Meer). Eurofins Omegam B.V., Eurofins AquaSense. $142 \mathrm{p}$.

Wolff, W.J., 1973. The estuary as a habitat. An analysis of data on the soft-bottom macrofauna of the estuarine area of the rivers Rhine, Meuse and Scheldt. Brill, Leiden.

Ysebaert, T., Craeymeersch, J.A.M., Wal, D.v.d., 2016a. De relatie tussen bodemdieren en hydro- en morfodynamiek in het sublitoraal en litoraal van de Westerschelde. IMARES.

Ysebaert, T., van der Werf, J., de Ve, t.L., Bouma, T.J., 2016b. Monitoringsplan Roggenplaat suppletie. Centre of Expertise Delta Technology, Wageningen Marine Research rapport.

Zandvoort, M., van der Zee, E., Vuik, V., 2019. De effecten van Zeespiegelstijging en Zandhonger op de Oosterschelde. Eindrapport van de studie EZZO: Tauw BV, Altenburg \& Wymenga en HKV Lijn in Water. I.o.v. Rijkswaterstaat Zee en Delta. Utrecht / Middelburg.

Zwarts, L., 2009. Voedsel voor wadvogels in de Oosterschelde. Altenburg \& Wymenga, Feanwâlden.

Zwarts, L., Blomert, A.-M., Bos, D., Sikkema, M., 2011. Exploitation of intertidal flats in the Oosterschelde by estuarine birds, A\&W rapport 1657. Altenburg \& Wymenga ecologisch onderzoek, Feanwâlden. 


\section{Verantwoording}

Rapport C071/21

Projectnummer: 4318100312

Dit rapport is met grote zorgvuldigheid tot stand gekomen. De wetenschappelijke kwaliteit is intern getoetst door een collega-onderzoeker en het verantwoordelijk lid van het managementteam van Wageningen Marine Research

Akkoord:

Dr. S. van Donk

Onderzoeker

Handtekening:

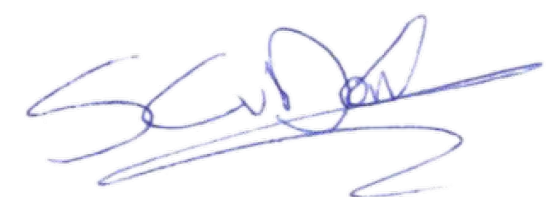

Datum:

28 september 2021

Akkoord:

Drs. J. Asjes

Manager Integratie

Handtekening:

Datum:

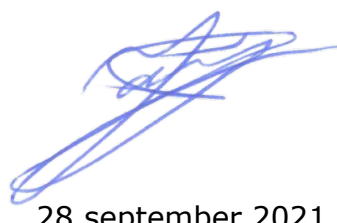


Bijlage 1. Trends in de gemiddelde dichtheid (ind/ $\mathrm{m}^{2} \pm$ standaardfout) van een aantal bodemdieren in de vier deelgebieden van de Oosterschelde (MWTL; 1992-2017 met uitzondering van 2015 en 2016, deelgebied Midden vanaf 2009)

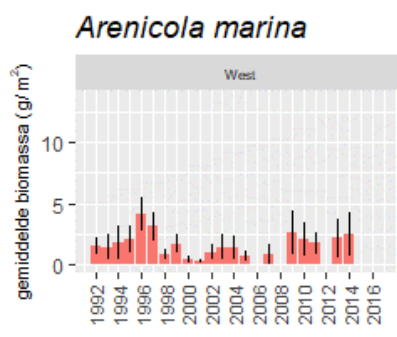

Bathyporeia sp.
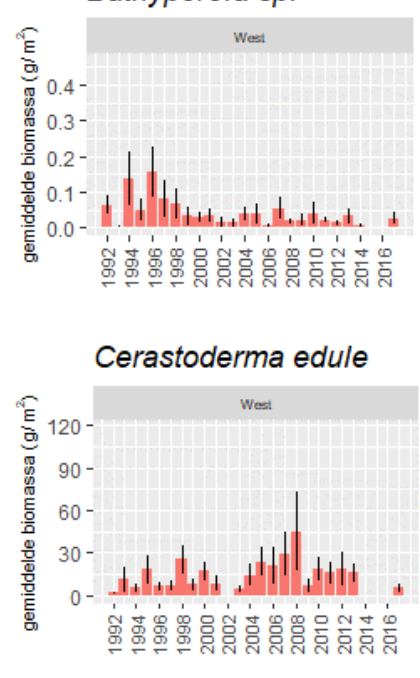

Corophium arenarium

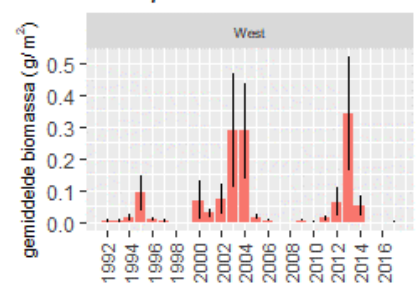

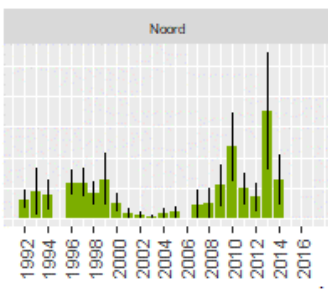
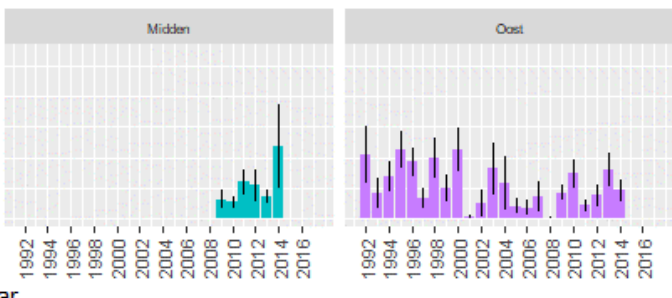
jaar
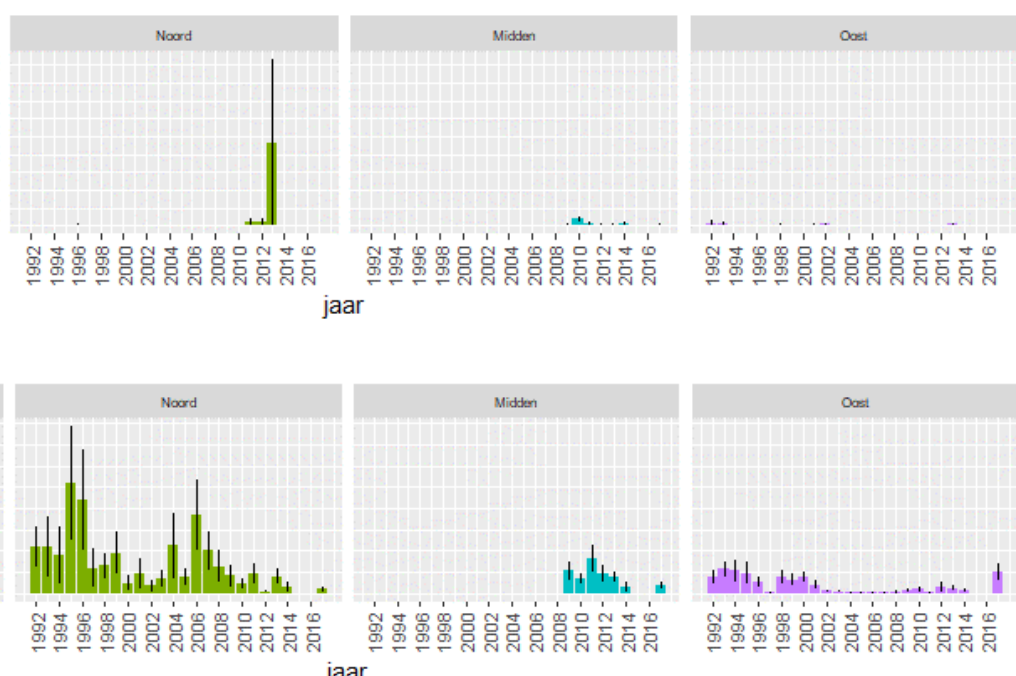

jaar
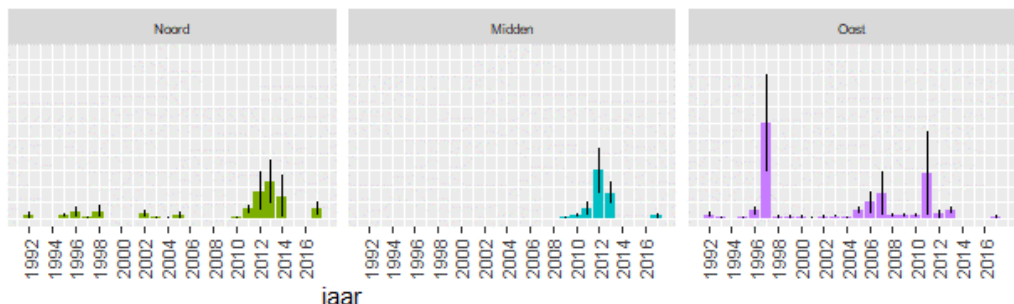

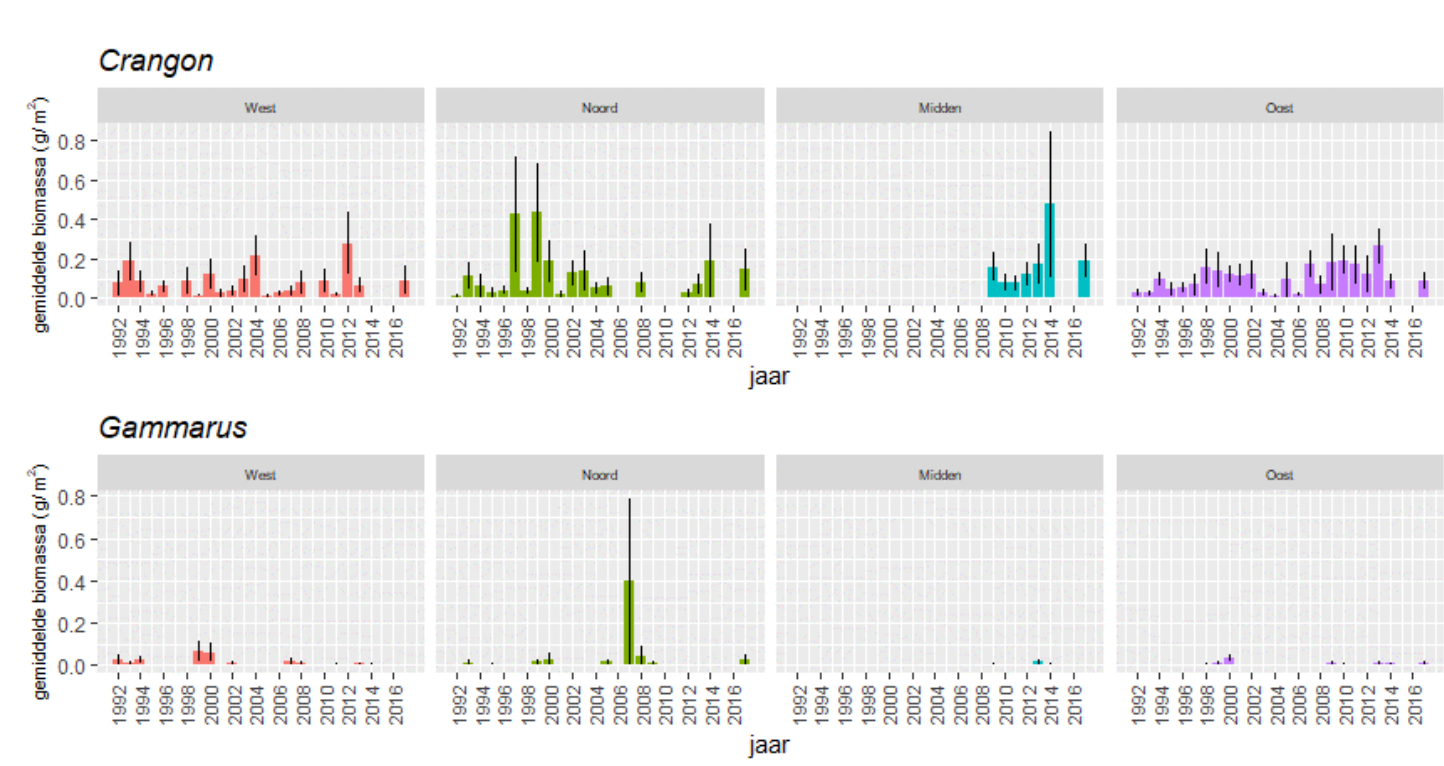

Hediste diversicolor
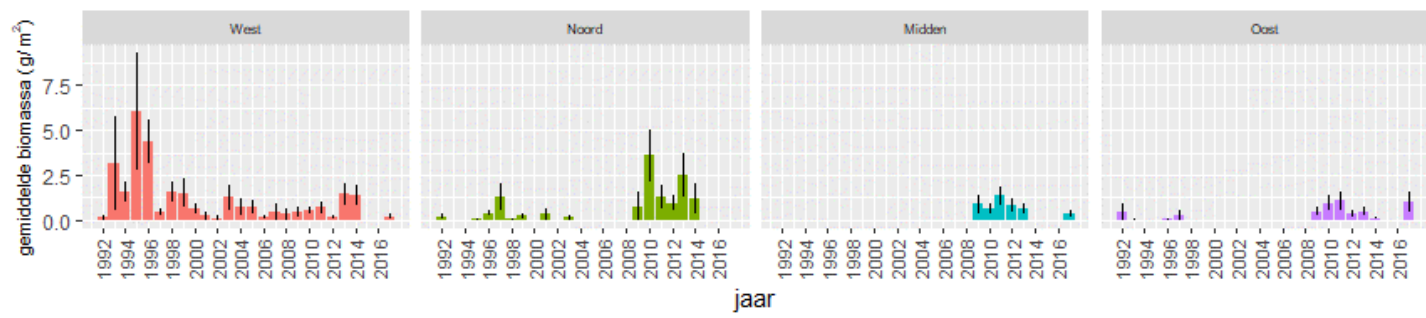

Heteromastus filiformis

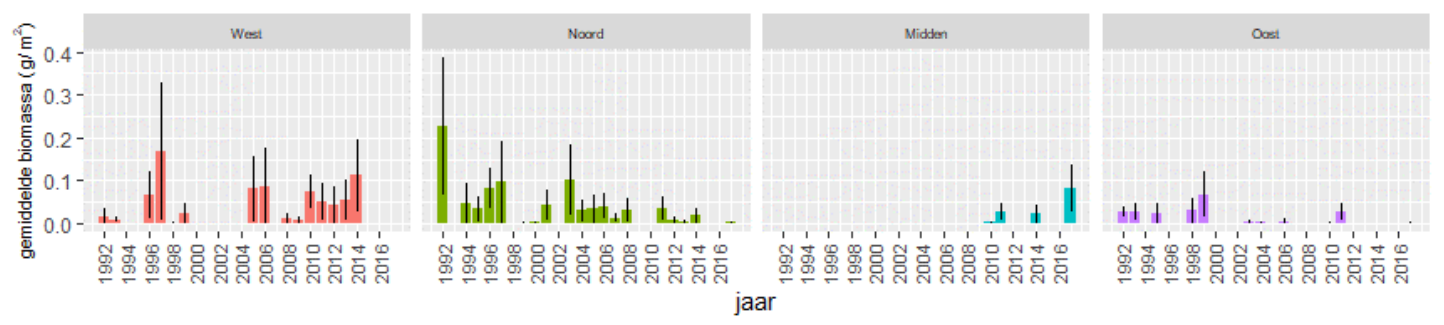




\section{Lanice conchilega}
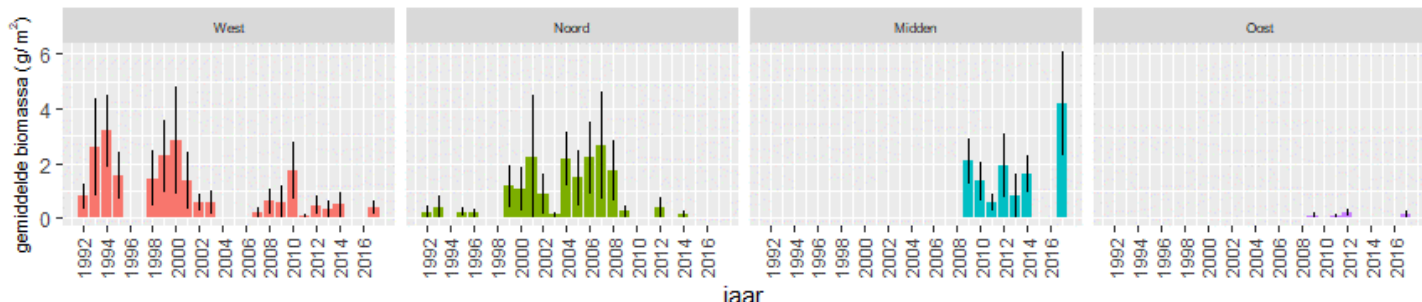

Limecola balthica
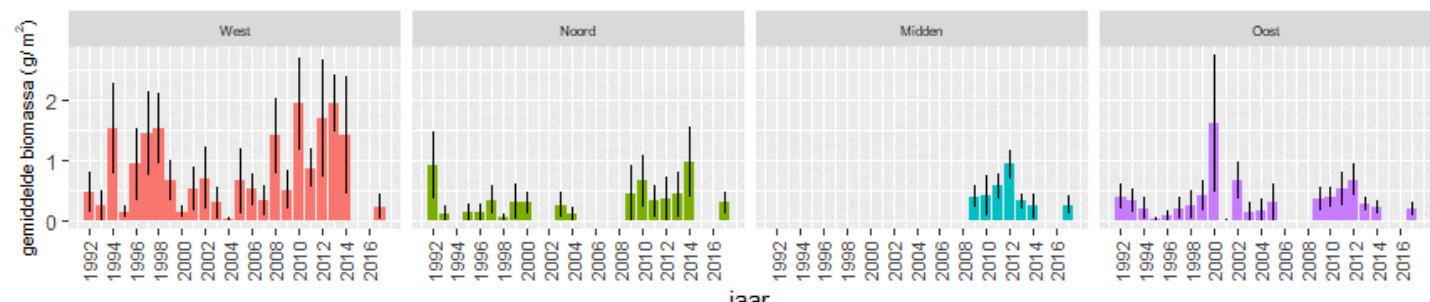

Nephtys hombergii
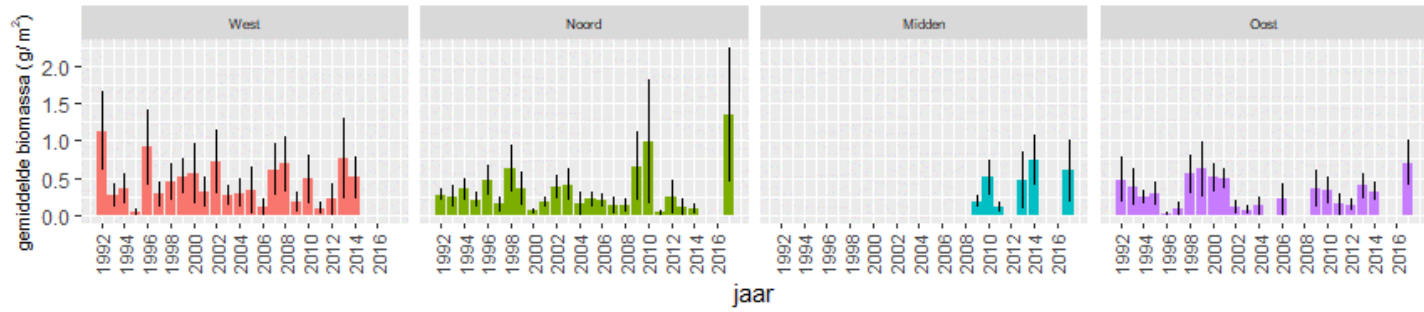

Pygospio elegans

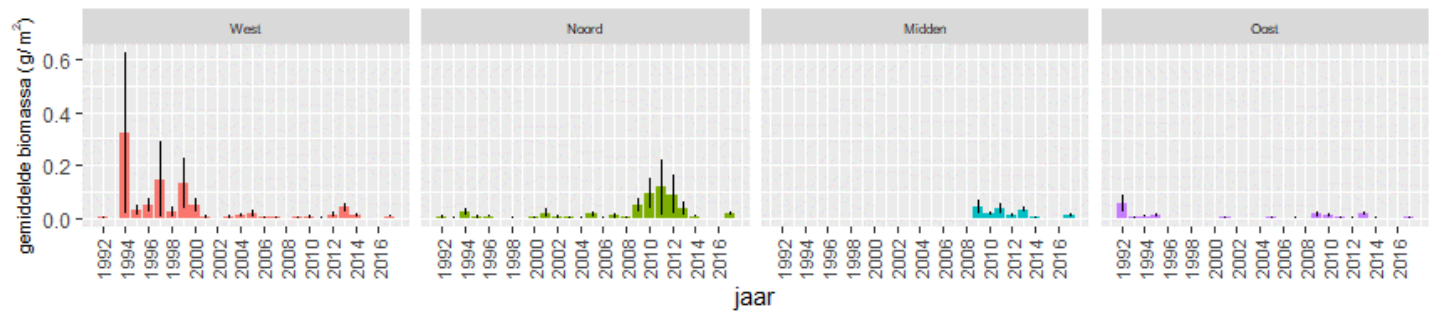




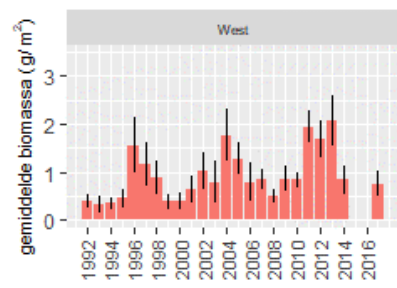

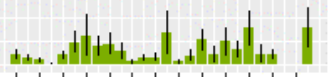

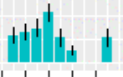

Midan

cost

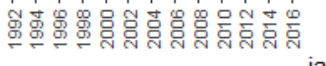
jaar

\section{Peringia ulvae}
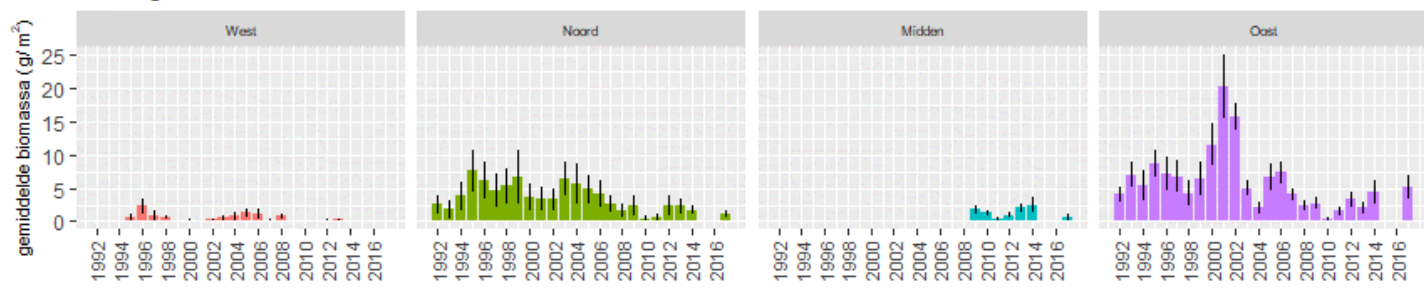

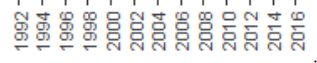

jaar 
Bijlage 2. Trends in de gemiddelde biomassa ( $g A F D W / m^{2} \pm$ standaardfout) van een aantal bodemdieren in de vier deelgebieden van de Oosterschelde (MWTL; 1992-2017 met uitzondering van 2015 en 2016, deelgebied Midden vanaf 2009) 


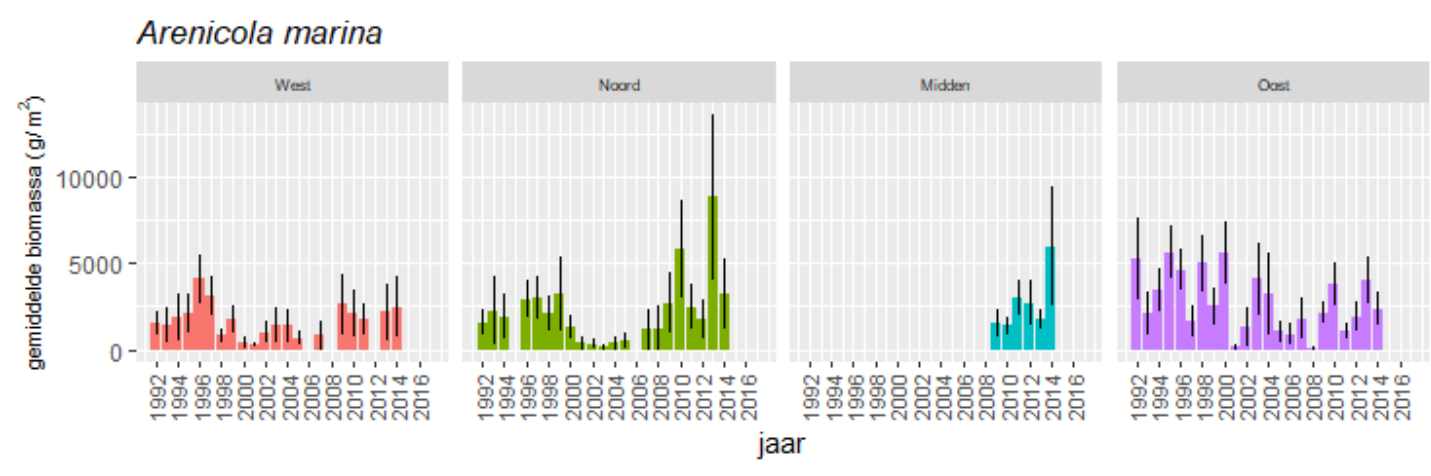

Bathyporeia sp.
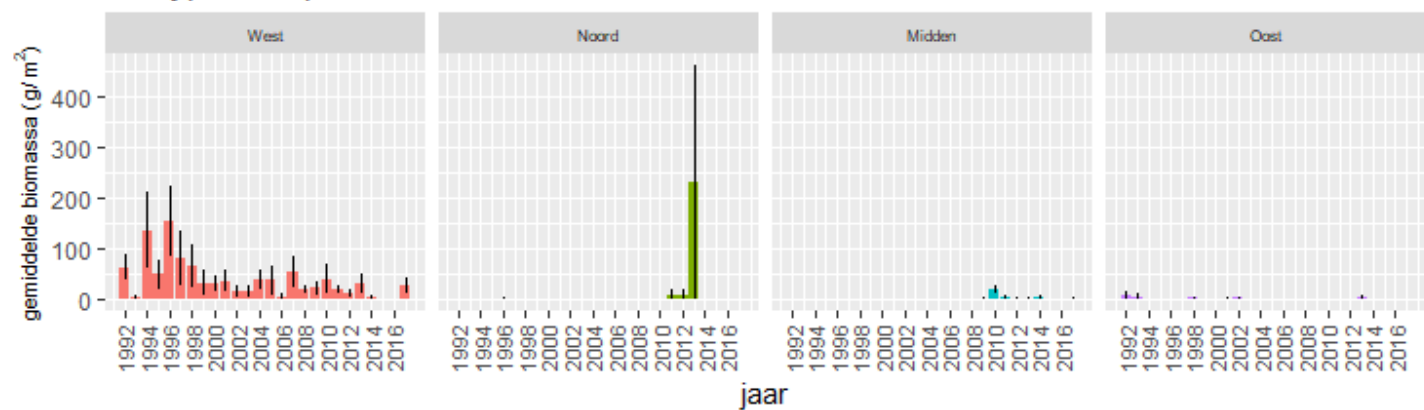

\section{Cerastoderma edule}
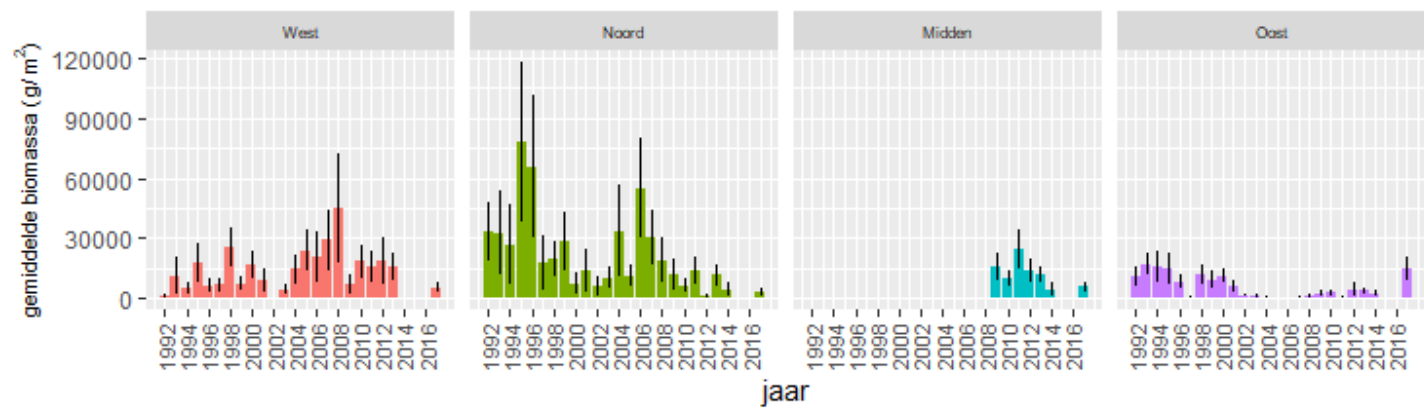

\section{Corophium arenarium}
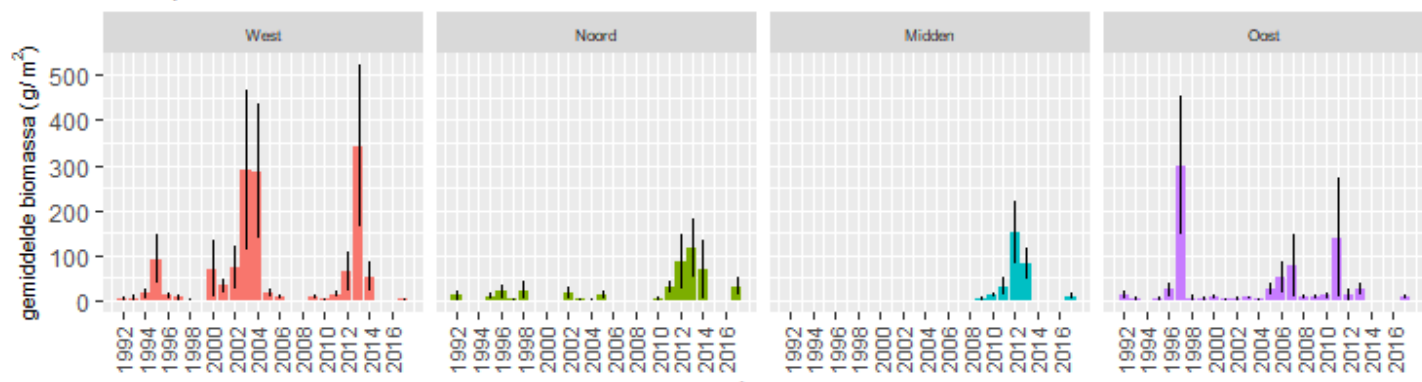

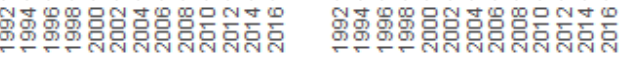



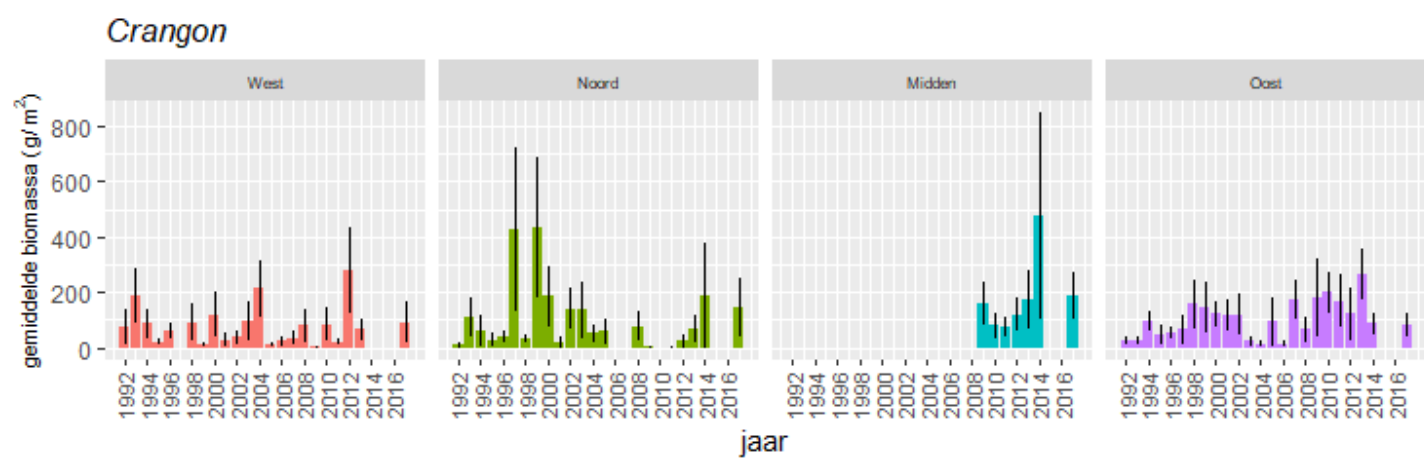

\section{Gammarus}
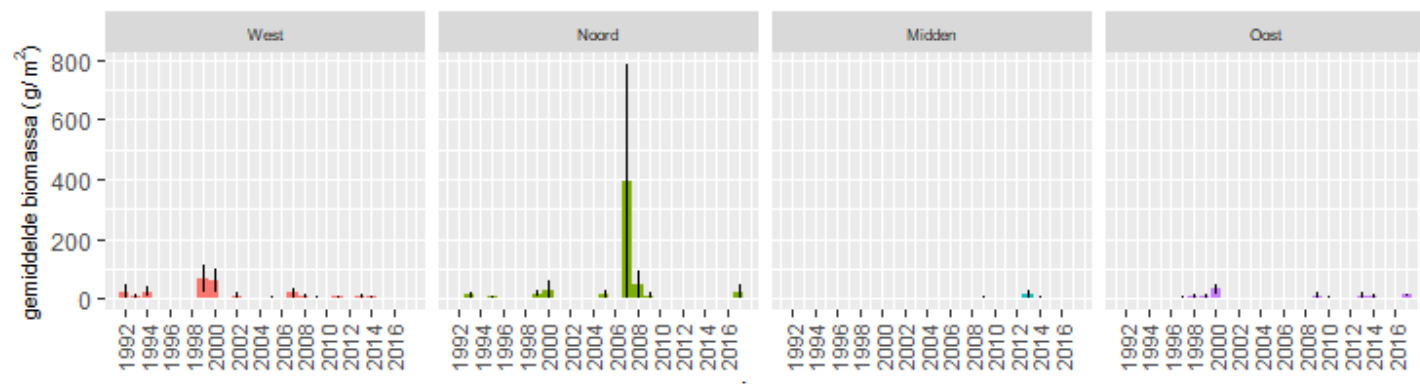

jaar

Hediste diversicolor
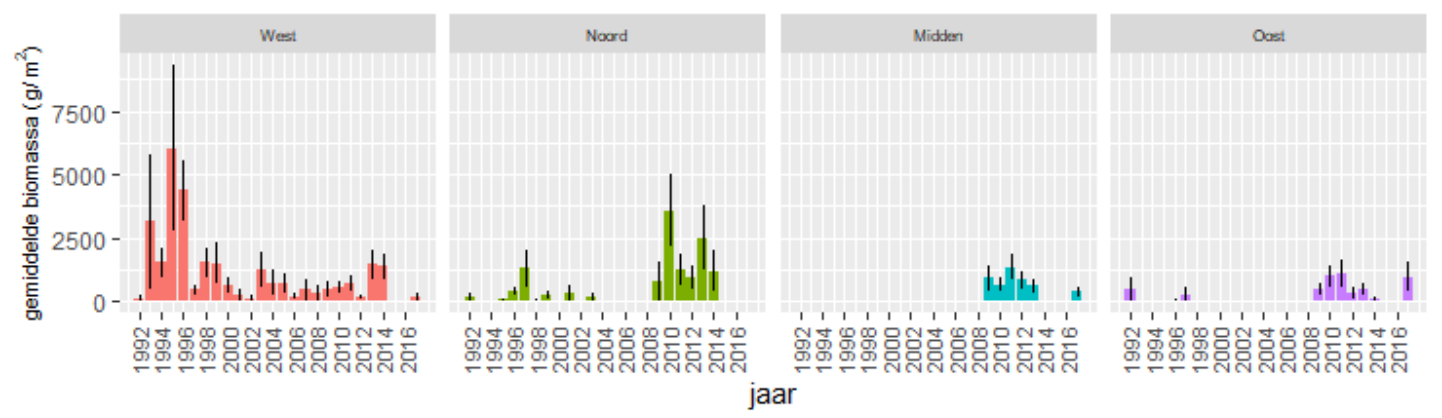

Heteromastus filiformis
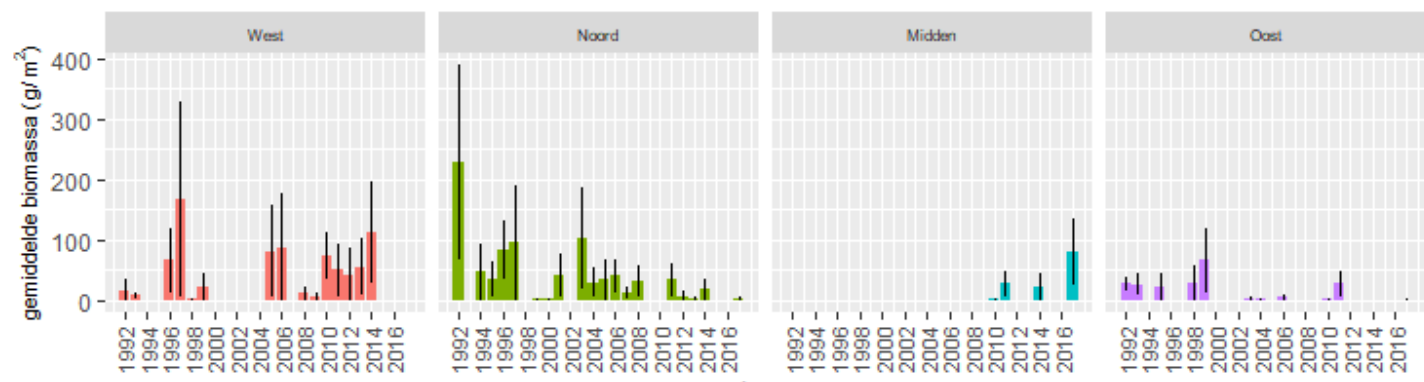

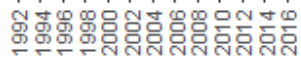

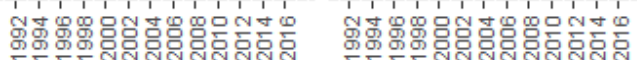
jaar 

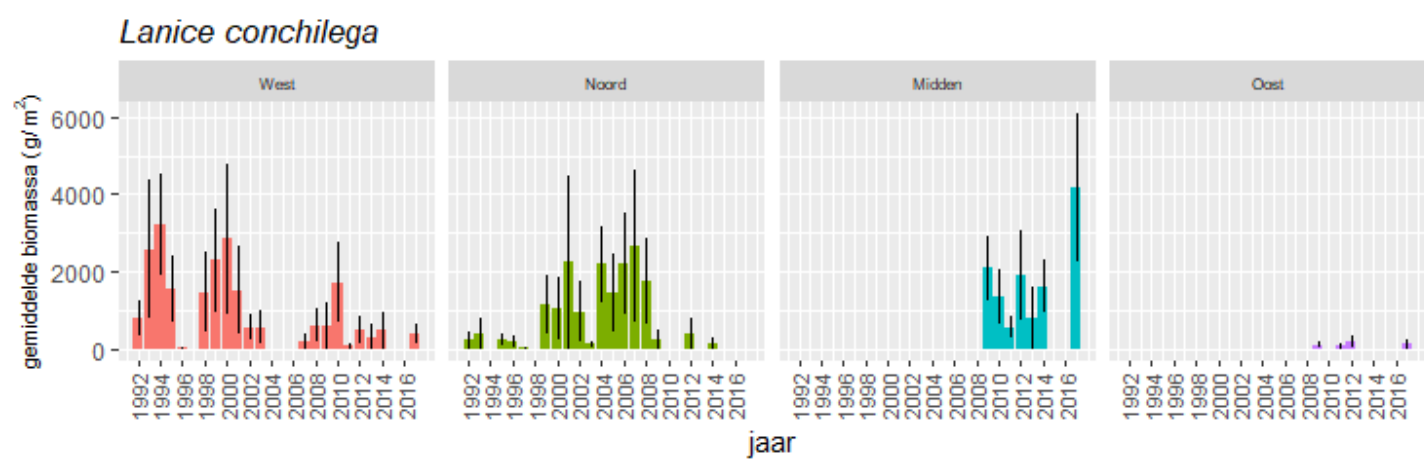

Limecola balthica
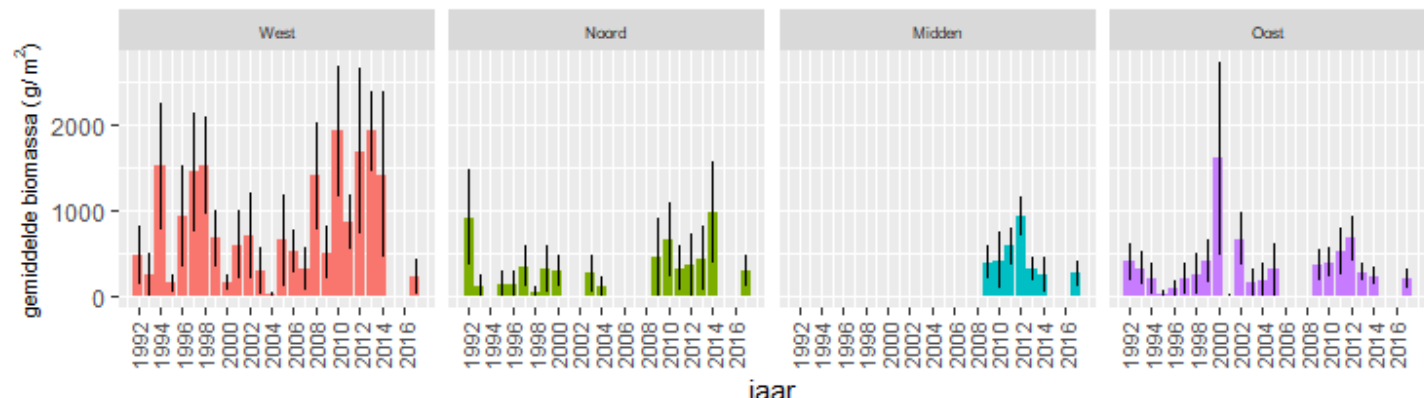

Nephtys hombergii
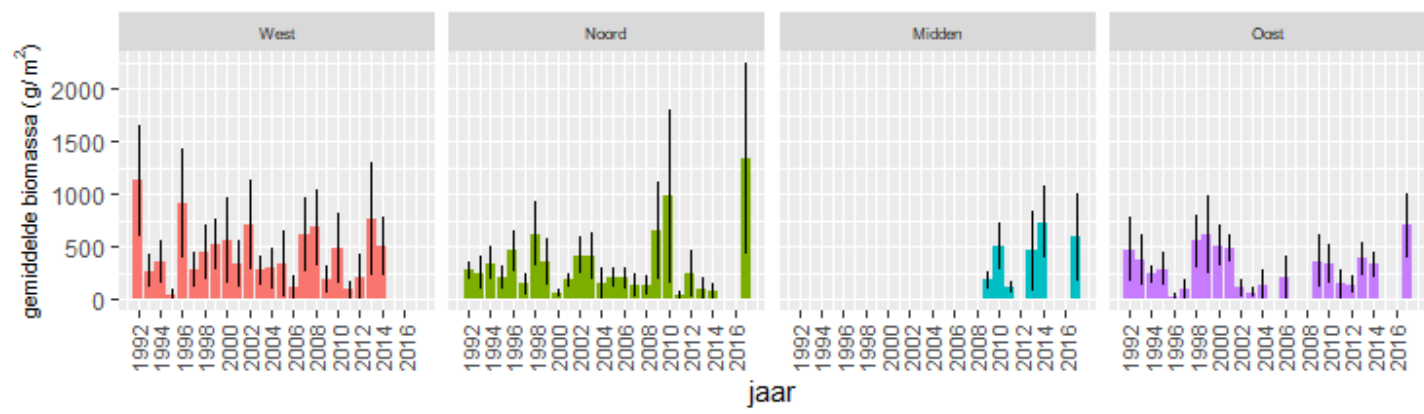

Pygospio elegans
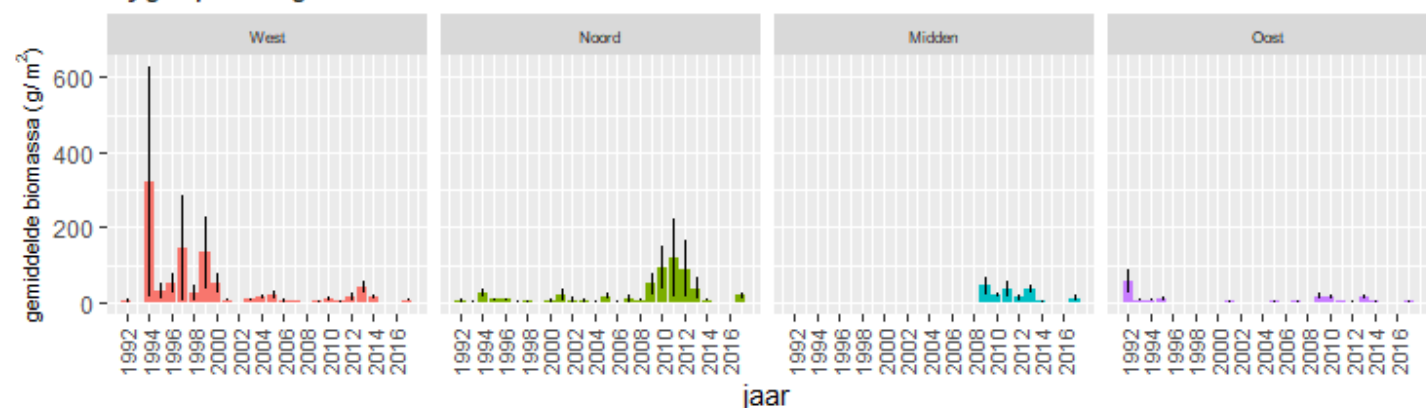
Scoloplos armiger

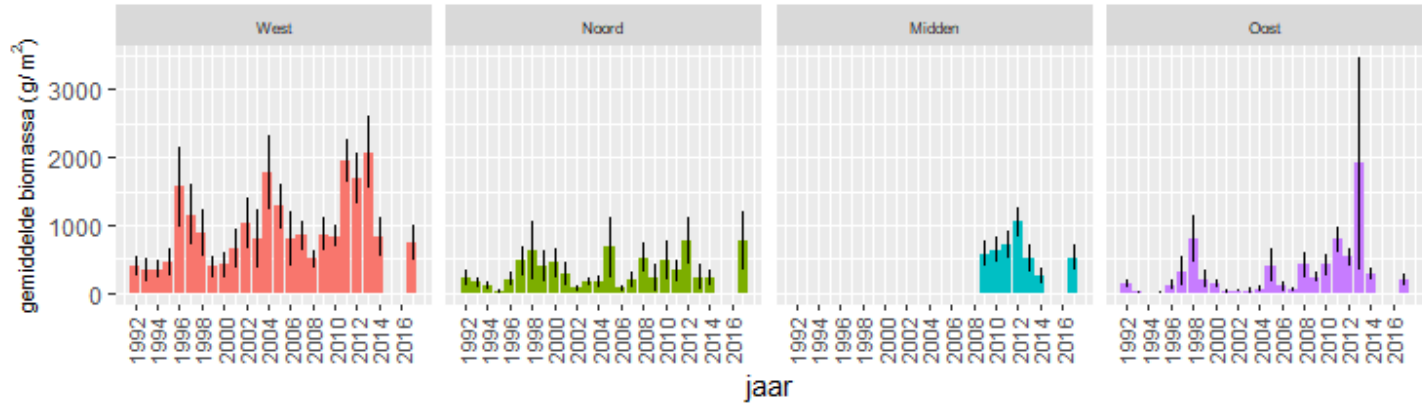

\section{Peringia ulvae}
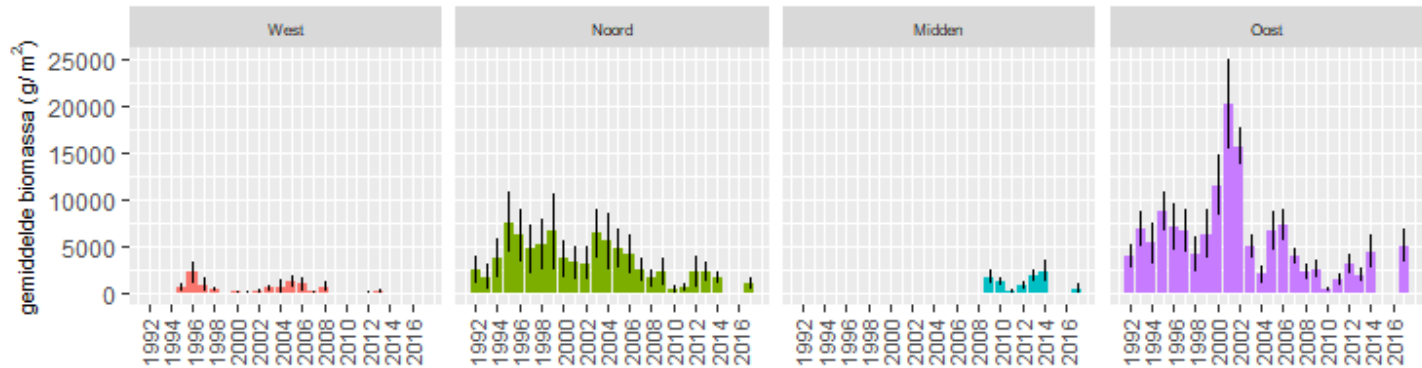

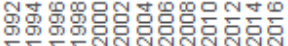

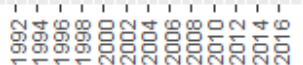

jaar 
Wageningen Marine Research

T: $+31(0) 317480900$

E: marine-research@wur.nl

www.wur.nl/marine-research

Bezoekers adres:

- Ankerpark 271781 AG Den Helder

- Korringaweg 7, 4401 NT Yerseke

- Haringkade 1, 1976 CP IJmuiden
Wageningen Marine Research levert met kennis, onafhankelijk wetenschappelijk onderzoek en advies een wezenlijke bijdrage aan een duurzamer, zorgvuldiger beheer, gebruik en bescherming van de natuurlijke rijkdommen in zee-, kust- en zoetwatergebieden.
Wageningen Marine Research is onderdeel van Wageningen University \& Research. Wageningen University \& Research is het samenwerkingsverband tussen Wageningen University en Stichting Wageningen Research en heeft als missie: 'To explore the potential of nature to improve the quality of life' 